
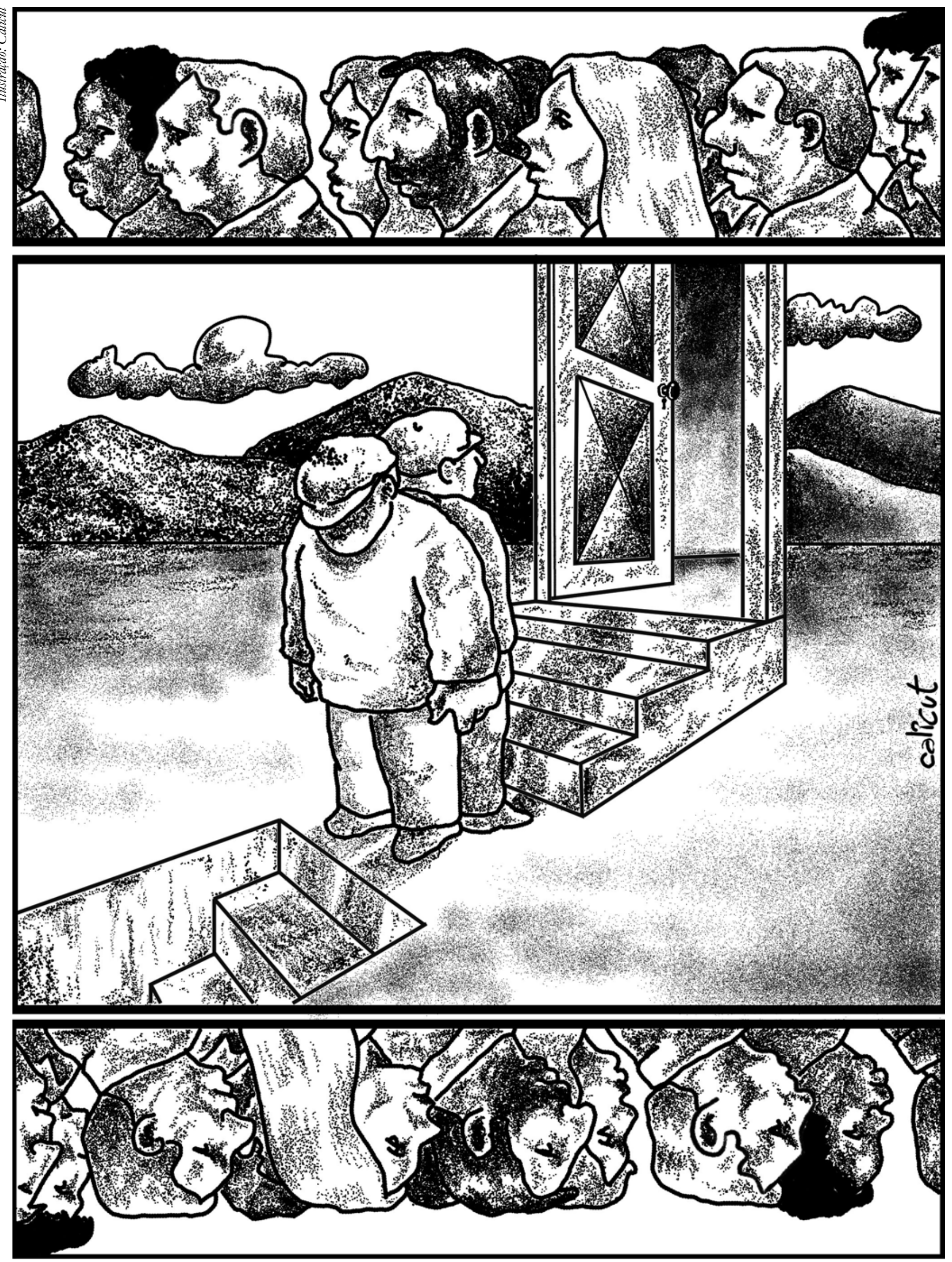


\title{
FORMAR E GERIR COMPETÊNCIAS: O CASO DE EMPRESAS MULTINACIONAIS DO SECTOR METALOMECÂNICO EM PORTUGAL
}

\author{
Cristina Parente ${ }^{*}$
}

\begin{abstract}
Resumo
A problemática da construção social das competências profissionais é o objecto central deste artigo. São discutidos os principais resultados de um projecto de investigação que incidiu sobre dois estudos de caso realizados em empresas multinacionais do sector metalomecânico localizadas em Portugal. As modalidades de gestão de competências são estudadas a partir da análise das lógicas de produção de saberes e de mobilização de competências, tendo em atenção o duplo ponto de vista dos dirigentes e dos assalariados. Termina-se a reflexão discutindo os principais determinantes empresariais da construção das competências profissionais.
\end{abstract}

Palavras-chave: Competências; Saberes; Empresas; Organização do Trabalho; Modelos de Gestão.

\section{O PRoblema teórico e a ESTRATÉgia metodológica DE ANÁLISE DAS COMPETÊNCIAS PROFISSIONAIS}

A importância da temática das competências e a emergência do modelo de competência são as respostas teórico-práticas da gestão dos Recursos Humanos $(\mathrm{RH})$ às transformações que emergiram no trabalho, no emprego e nas empresas nas últimas décadas do século XX.

Neste artigo discute-se, sob uma perspectiva organizacional, a aquisição, a estimulação e o desenvolvimento de competências profissionais ${ }^{1}$. Questiona-se o exercício de uma actividade profissional do ponto de vista do seu contributo para o processo de formação dos saberes ou, dito de outra forma, procura-se perceber se o desempenho laboral se resume ao desenvolvimento de saberes pré-constituídos, ou, pelo contrário, se em função do conteúdo da actividade de trabalho se constroem saberes, se renovam outros e se destituem iguais, num processo cumulativo, que funciona por osmose entre uns, rejeição de outros e integração de todos. O estudo da dinâmica dos saberes pela

\footnotetext{
Licenciada e doutorada em Sociologia pela Faculdade de Letras da Universidade do Porto (Flup), e mestre em Políticas e Gestão de Recursos Humanos pelo Instituto Superior de Ciências do Trabalho e da Empresa (1scte). Professora auxiliar no Departamento de Sociologia e investigadora do Instituto de Sociologia da Faculdade de Letras do Porto. E-mail: cparente@letras.up.pt.
}

Recebido para publicação em: 04/03/08 mobilização de competências remete para o carácter qualificante e desqualificante do desempenho laboral. É nesse sentido que se consideram que as competências não estão imbuídas apenas da qualificação do emprego, isto é, das suas exigências em termos de capacidades requeridas para o ocupar, e da qualificação do trabalhador, ou seja, das suas formações escolar e profissional. São, antes, o resultado de escolhas condicionadas pelas configurações organizacionais e gestionárias, que podem manifestar-se mais ou menos favoráveis ou desfavoráveis à sua estimulação, desenvolvimento e reconhecimento.

É no contexto social de intensificação de aplicação das Tecnologias da Informação e da Comunicação (TIC) que, do ponto de vista teórico - particularmente no âmbito da Sociologia do Trabalho, das Organizações e da Empresa -, se inicia a utilização do conceito de competência. Este ganha força em detrimento do conceito de qualificação para dar conta quer da dimensão organizacional implicada na formação e desenvolvimento das mesmas, quer dos saberes de carácter informal e implícito que o conceito de qualificação "obscurece", nomeadamente os saberes relacionais. Assim sendo, o paradigma de análise das competências vai permitir estudar a introdução e difusão das TIC e de novos métodos de organização e de gestão da produção ao integrar requisitos diferentes no domínio dos saberes, em termos do seu processo de construção, do seu conteúdo e da sua natureza. Em suma, permite dar sentido ao alargamento do campo de saberes requeridos aos trabalhadores do núcleo operacional das empresas no seio do estado actual das práticas da actividade de trabalho 
e, simultaneamente, alerta para a necessidade de se adoptarem medidas concorrentes à sua gestão. Daí a transição entre a lógica e o modelo da qualificação para o da competência.

Édentro dessa linha que se destaca Zarifian $(1994)^{2}$, sociólogo francês que vem desenvolvendo a sua actividade de investigação no seio deste paradigma. $O$ autor argumenta que, por um lado, a qualificação não se reduz ao conjunto de saberes detidos pelos sujeitos e utilizados na actividade profissional, na medida em que esta abordagem ignora o papel da organização; por outro lado, a concepção de qualificação do emprego exclui a possibilidade dos indivíduos modificarem e modelarem o conteúdo da actividade de trabalho como resultado da sua acção; finalmente, a concepção de qualificação do trabalhador impõe o impasse do não reconhecimento dos saberes detidos pelos sujeitos, desde que não utilizados no âmbito do emprego ocupado e da organização em que se inserem. As noções de qualificação do trabalhador e de posto de trabalho (ou emprego) remetem para uma lógica prescritiva e objectivada, típica do modelo da organização científica do trabalho (OCT) e de gestão dos RH, adaptados a uma envolvente estável. À noção de competências subjaz uma lógica dinâmica, flexível e de instabilidade que faz apelo à competência dos trabalhadores, dada "a necessidade de gerir a incerteza e a imprevisibilidade das situações profissionais" (VALENTE, 1999) ${ }^{3}$.

Zarifian (1996a; 2002a) ${ }^{4}$ diferencia entre duas variantes do modelo de competências, as quais, apesar de interligadas, apresentam uma diferença fundamental quanto ao papel atribuído às competências dos RH na estratégia das empresas. Numa, gere-se o desenvolvimento da estratégia da empresa e o desempenho empresarial pela utilização e desenvolvimento das competências e, na outra, gere-se, prioritariamente, o desenvolvimento e a mobilização de competências.

A primeira é designada por gestãopela competência (no singular), porque o objectivo prioritário é pôr em curso a estratégia da empresa para a qual a competência é considerada um recurso central, cabendo-lhe assegurar o sucesso da mesma. É também designada de política da competência, na medida em que a competência é usada de forma instrumental enquanto meio ao serviço da estratégia, quer na sua definição, quer na sua implementação, encontrando-se fortemente relacionada com as escolhas organizacionais das empresas (ZARIFIAN, 1996a; 2002a) ${ }^{5}$.

Contrariamente, a gestão das competências (no plural) situa-se do lado dos indivíduos, com um duplo objectivo de desenvolver e proporcionar recursos em competências necessários a garantir a política da competência (ou seja, de garantir a primeira variante), por um lado, e de ter em conta as aspirações individuais dos trabalhadores, o sentido que atribuem ao seu trabalho e as suas perspectivas pessoais, a necessidade de coesão social, de equilíbrios sociais e de reconhecimento a que os sujeitos legitimamente aspiram, por outro (ZARIFIAN, 1996a; 2002a) ${ }^{6}$. Nessa variante, para o exercício da competência (no singular) é imprescindível que os trabalhadores disponham de possibilidades de desenvolvimento das competências (no plural), ou seja, dos saberes e das atitudes que lhes permitem confrontar, com sucesso, uma situação de trabalho, dominá-la, pensá-la e desenvolver as acções de trabalho adequadas.
Essas duas variantes devem sustentar-se mutuamente, mas não se fundem uma na outra necessariamente. $\mathrm{Na}$ primeira, afirmam-se os objectivos das empresas. Na segunda, as expectativas e os projectos dos trabalhadores, e se ambos se devem reforçar, não se podem confundir, havendo sempre em menor ou maior grau oposições entre ambos.

Relacionando as duas variantes do modelo de competências com as práticas de gestão dos $\mathrm{RH}$ a partir da aplicação de uma tipologia construída noutro trabalho ${ }^{7}$, é-se conduzido a afirmar que, no modelo de competências, as práticas de gestão dos $\mathrm{RH}$ imediatistas e utilitaristas (PARENTE, 1995) não têm lugar ao tratarem-se de modalidades de gestão típicas do modelo da qualificação, adaptadas aos princípios clássicos de organização do trabalho e da gestão do pessoal. Le Boterf $(1998 a)^{8}$ denuncia ser nesse âmbito que se utiliza abusiva e ideologicamente o conceito de competências. Estas são equiparadas a um saberfazer fragmentário, e os referenciais de competências a listas intermináveis de saberes. As competências aparecem reduzidas a fragmentos, perdendo todo o seu sentido. A lógica da decomposição é incompatível com a de autonomia, de responsabilidade e de empenho exigidos pelo modelo de competências.

Se nos centrarmos na variante da gestão pelas competências, esta tenderá a estar associada a uma gestão de RH de carácter adaptativo e de ajustamento (PARENTE, 1995) ${ }^{9}$, em que o principal

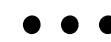

\section{para o exercício da} competência (no singular) é imprescindivel que os trabalhadores disponham de possibilidades de desenvolvimento das competências (no plural), ou seja, dos saberes e das atitudes que lhes permitem confrontar, com sucesso, uma situação de trabalho, dominá-la, pensála e desenvolver as acções de trabalho adequadas. 


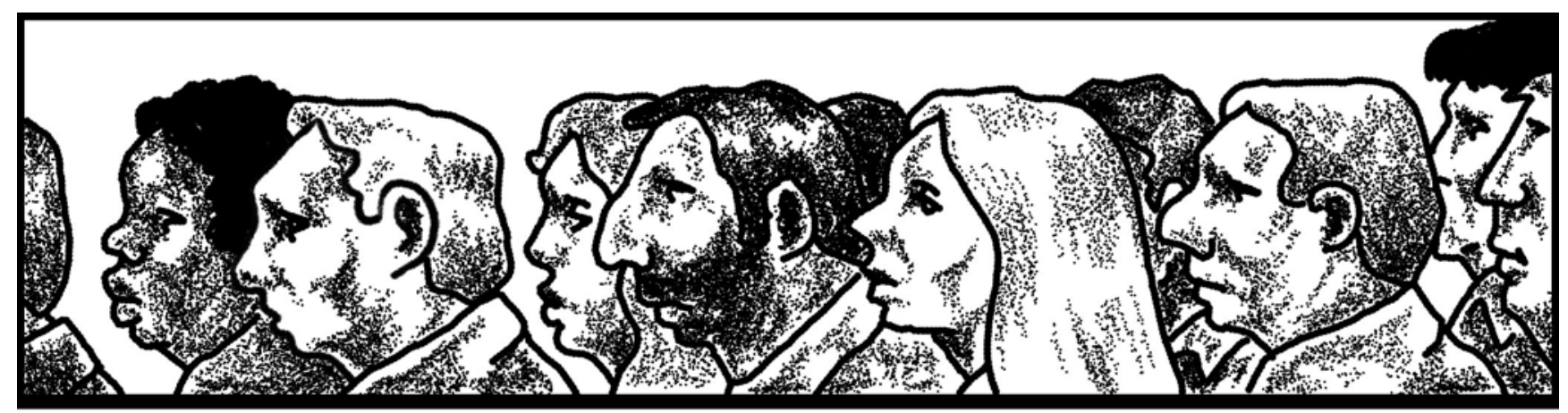

fito da mesma é a prossecução da estratégia da empresa. Desse modo, promovem-se práticas de gestão dos RH distintas entre os trabalhadores que se apresentam como um recurso insubstituível para o sucesso dos resultados e os restantes trabalhadores das empresas. Os primeiros são integrados no mercado interno de trabalho ${ }^{10}$, sendo alvo de práticas de gestão de RH não precarizantes e evolutivas, ao contrário dos segundos, que tendem a ser geridos de acordo com parâmetros de flexibilidade quantitativa externa, ao estarem afectos a um mercado de trabalho não qualificado e ocasional (MARSDENS, 1989) ${ }^{11}$.

A gestão das competências remete para uma gestão dos RH numa perspectiva desenvolvimentista e estratégica (PARENTE, 1995) $)^{12}$. Para além de práticas de gestão dos RH que incentivam a produção de saberes e a mobilização das competências dos trabalhadores, põem-se em prática modos de organização e conteúdos da actividade de trabalho que procuram não desperdiçar os RH, bem pelo contrário, procuram potenciá-los, ao promoverem uma articulação gratificante entre o desempenho laboral dos trabalhadores e o desempenho empresarial. É nessa perspectiva que Zarifian defende que, antes de "gerir as competências, é preciso definir em que medida a mobilização da competência é um modo de gestão da empresa, isto é, gerir as competências, antes de gerirpelas competências" (1996a) $)^{13}$. Remete, assim, para um modo de gestão baseado no envolvimento social e profissional, na cooperação e na responsabilidade que, pelos seus efeitos socioprofissionais, se sobrepõe à gestão dos empregos. Pressupõe ainda uma revisão das práticas de formação profissional, o seu enquadramento no seio das políticas de gestão das pessoas (e não dos empregos) e, sobretudo, a articulação daquelas com as opções de organização de trabalho.

Essas práticas rompem com uma abordagem individualizante e auto-centrada das competências. Segundo Zarifian $(1998 a)^{14}$, a construção individual das competências faz-se por referência a situações profissionais, no sentido em que assumem a dimensão eminentemente colectiva e socializada do trabalho, cujas condições podem ser mais ou menos favoráveis ao seu desenvolvimento. Por um lado, os próprios recursos não se encontram todos na posse do sujeito. Cada indivíduo tem uma rede de relações informais e de bases informacionais - segundo Le Boterf $(1997)^{15}$, o quarto cérebro - e as suas competências dependem da sua capacidade para aceder e para tratar essa rede de conhecimentos. Por outro, um trabalhador não é competente de forma isolada, mas com os seus instrumentos de trabalho, com os seus pares, com os especialistas que consulta, com a rede de clientes e fornecedores com que se relaciona e com os suportes institucionais que o apoiam (ZARIFIAN, 1998a) ${ }^{16}$. Assim, a dimensão organizacional é uma variável chave a ter em conta no modelo de competências. Paralelamente, a mobilização de competências implica um reconhecimento encarado não como uma "recompensa pela leal prestação de serviços", mas como uma condição de desenvolvimento dos indivíduos e das suas competências. E, na perspectiva de Zarifian (1998b) ${ }^{17}$, a organização do trabalho pode ser pensada como mecanismo de reconhecimento, tal como as práticas de gestão dos $\mathrm{RH}$, pela forma de funcionamento da organização, pelas relações hierárquicas que permite, pela qualidade das relações sociais que cria. Podemos dizer que a variante da gestão das competências resulta então de uma combinação entre configurações gestionárias e organizacionais.

Essa foi a matriz teórica analítica utilizada no processo de investigação aqui visado. A argumentação adoptada relaciona-se com o facto de a produção de saberes e a sua mobilização em competências depender de condições facilitadoras e/ou inibidoras que as empresas criam por via da gestão organizacional do quotidiano de trabalho (figura 1). Tal situação é fomentada, por um lado, por intermédio dos modelos de organização do trabalho e do conteúdo da actividade laboral e, por outro, por via das práticas de gestão dos RH e dos modelos de gestão directa, assentes em princípios de poder e de estruturação hierárquica ${ }^{18}$. $\mathrm{Na}$ análise proposta, modelos e práticas organizacionais e gestionárias constituem as variáveis independentes que, definidas ao nível meso, explicam a produção de saberes e a mobilização de competências em contextos empresariais. A gestão organizacional do quotidiano de trabalho (figura 1) é, por sua vez, condicionada a montante pelas estruturas organizacionais e gestionárias, definidas ao nível macro-empresarial pelos dirigentes do topo estratégico que determinam, em última instância, a orientação das empresas para a aprendizagem, isto é, delas deriva o carácter mais ou menos favorável que as variáveis organizacionais, por um lado, e as variáveis gestionárias, por outro, podem assumir face às oportunidades de aprendizagem por parte dos sujeitos, bem como da partilha e generalização da aprendizagem nos níveis colectivo (grupo/equipa) e organizacional (empresa no seu todo).

A questão orientadora da pesquisa versou as relações que, no seio de duas empresas da indústria metalomecânica, se estabele- 
cem entre as práticas de mudança organizacional, a aprendizagem de saberes e a mobilização de competências dos trabalhadores do núcleo operacional ${ }^{19}$.

Consideraram-se os espaços de trabalho enquanto espaços de formação de saberes, mas também como espaços de estagnação ou de regressão dos mesmos. É o primeiro enunciado que orienta o raciocínio de descoberta desenvolvido e, nesta óptica, junta-se-lhe um outro prisma analítico que salienta uma maior probabilidade de desenvolvimento dos processos de aprendizagem em situações de mudança organizacional. Parte-se da pressuposição de que as empresas que têm em curso projectos de mudança organizacional integram em si características mais favoráveis ao desenvolvimento de processos de aprendizagem por parte dos trabalhadores do núcleo operacional. A mudança pode constituir uma oportunidade de aprendizagem - esta oportunidade pode ou não concretizar-se, decorrente dos factores já enumerados e, ao concretizar-se, pode assumir uma amplitude mais ou menos vasta, aos níveis individual, colectivo (equipa/grupo) e organizacional (a empresa na sua totalidade).

Ao definir tal postulado analítico, circunscreveu-se o objecto empírico à análise de empresas envolvidas em práticas de mudança organizacional. A análise exploratória e os princípios e pressupostos teóricos adoptados orientaram-nos, do ponto de vista empírico, para uma metodologia de análise intensiva baseada em dois estudos de caso. Estes decorreram, durante o ano de 2001, em empresas do sector da metalomecânica envolvidas em práticas de mudança organizacional - a Lume e a Hame ${ }^{20}$ -, localizadas na zona centro do país e integradas em grandes grupos multinacionais.

O modelo analítico (figura1) que a seguir se apresenta sistematiza a cadeia interpretativa acabada de expor, a qual adquire uma configuração específica resultante da confluência entre os dois tipos de lógicas em interacção, a saber: as lógicas das empresas e as lógicas dos sujeitos. Nessa dinâmica, o primeiro tipo de lógica tende a sobrepor-se e dominar a segunda, a qual não deixa de ter autonomia, todavia relativa. O indivíduo é um sujeito dotado de um grau de autonomia relativa dentro do sistema empresarial, dispondo de uma margem de liberdade que não lhe omite a capacidade de acção, ainda que esta esteja sujeita a determinações estruturais e aos condicionamentos económicos e sociais impostos pelas empresas. Assim, também os sujeitos reproduzem e/ou concorrem para a transformação daqueles condicionamentos.

Nesse sentido, o processo de construção social das competências profissionais é sempre encarado numa dupla vertente, organizacional e individual, no qual se analisam os processos de aprendizagem de saberes e de mobilização das competências, duplamente condicionados:

(i) do lado empresarial: ao nível macro, pela estrutura organizacional e gestionária das empresas e pelo seu sistema de produção; ao nível meso, pela organização do trabalho e pelas práticas de gestão dos $\mathrm{RH}$, estas últimas integrando os modelos de gestão directa;

\author{
o processo de construção \\ social das competências \\ profissionais é sempre \\ encarado numa dupla \\ vertente, organizacional \\ e individual, no qual se \\ analisam os processos de \\ aprendizagem de saberes \\ e de mobilizacão das \\ competências, duplamente \\ condicionados
}

(ii) do lado do sujeito: pela trajectória profissional e educativa, variáveis que, apesar de gozarem de um estatuto de maior autonomia e exterioridade face às empresas, não deixam de estar condicionadas pela lógica organizacional e gestionária, bem como pelo sentido atribuído pelos sujeitos ao mundo vivido do trabalho e da formação.

O modelo analítico deve ser interpretado da esquerda para a direita de quem lê, isto é, focando a atenção primeiro nas variáveis inseridas nos rectângulos internos e nas respectivas relações presumidas. Só depois se deve atender às duas molduras externas do modelo: a moldura a tracejado engloba as variáveis organizacionais que, inter-relacionadas, constituem as condições organizacionais de aprendizagem; a moldura a cheio integra as variáveis que, inter-relacionadas, condicionam a aprendizagem individual. A sobreposição entre molduras refere-se às condições organizacionais e gestionárias que influenciam directamente os processos de aprendizagem individuais. Ou seja, as variáveis empresariais definidas em nível macro - primeira fileira de rectângulos de contornos tracejados cinza escuro e sombreados a cinza - condicionam indirectamente a aprendizagem individual, isto é, por via das variáveis de nível meso - segunda fileira de rectângulos brancos de contornos cinza tracejados -, sendo que são estas as variáveis que, por sua vez, condicionam directamente produção de saberes e a mobilização de competências, isto é, a terceira fileira de rectângulos brancos de contornos pretos.

A pertença dos trabalhadores a uma empresa particular enquanto elemento estruturador de configurações organizacionais e gestionárias próprias foi considerada, a título de hipótese teó- 
Figura 1

Modelo analítico

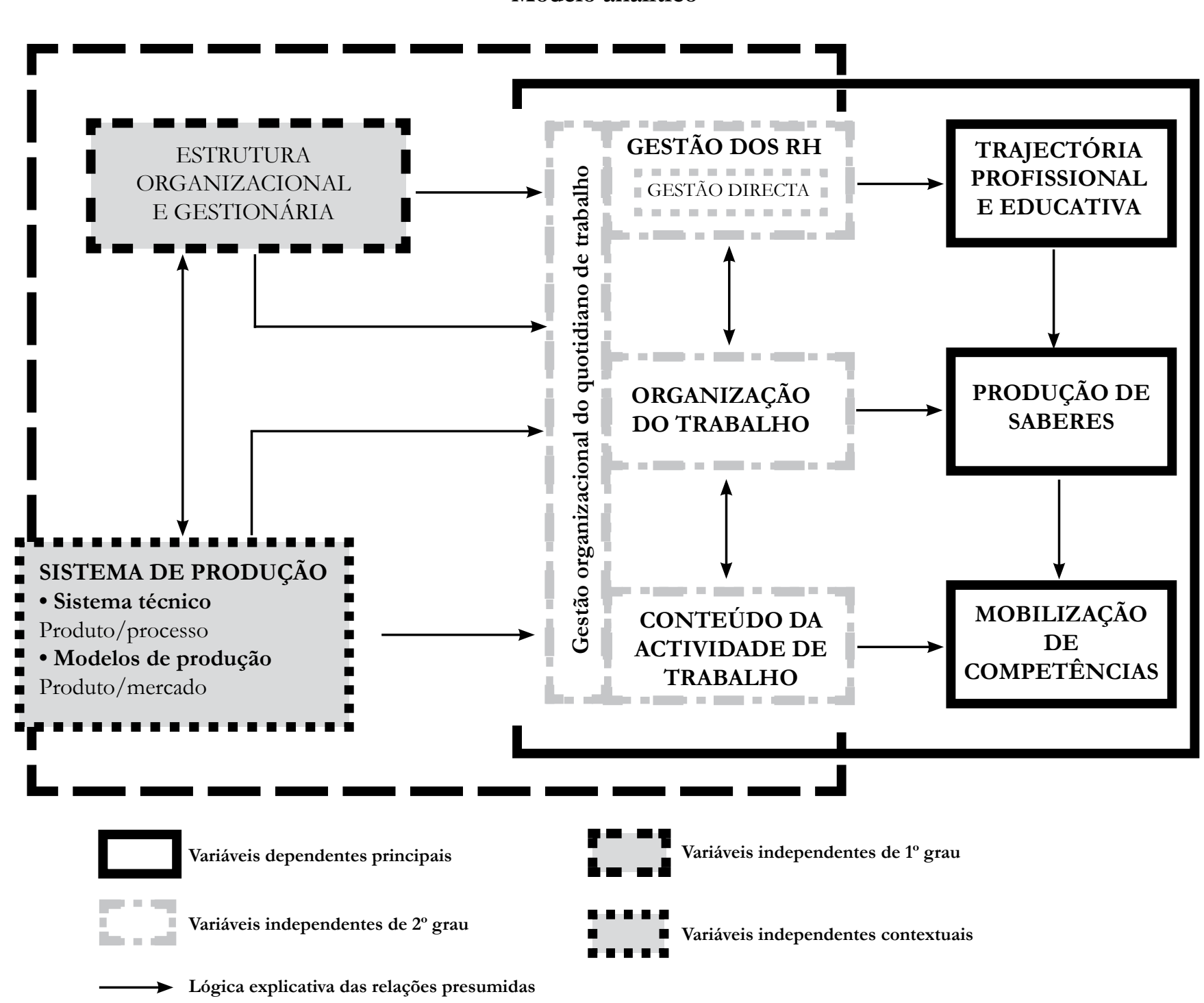

rica, o elemento distintivo principal das modalidades assumidas pelos processos de produção de saberes e de mobilização de competências.

De forma a testar essa hipótese, desenvolveram-se os dois estudos de caso, na Lume e na Hame. Em cada uma das empresas, estudaram-se duas actividades de trabalho integradas nos domínios de tarefas (MALGLAIVE, 1995) ${ }^{21}$ da montagem e da maquinação. Estas caracterizavam-se por serem actividades modais nas duas empresas, embora com incidências inversas, isto é, as actividades de trabalho integradas no domínio de tarefas da montagem predominam no seio da Lume, e as integradas no domínio de tarefas da maquinação eram maioritárias na Hame. Acresce que se tratavam de actividades de trabalho suficientemente distintas entre si, pois caracterizavam-se por conteúdos de trabalho com graus de complexidade desiguais - as primeiras apresentam um menor grau de complexidade comparativamente às segundas -, os quais exigem, por parte dos trabalhadores do núcleo operacional, saberes distintos, baseados numa formação escolar e profissional e numa experiência profissional igualmente, diferenciadas.

As técnicas de recolha de informação adoptadas na análise da produção de saberes e da mobilização de competências foram a observação directa da actividade de trabalho, a análise documental, a aplicação de entrevistas semi-directivas aos trabalhadores e aos responsáveis directos e de entrevistas estruturadas ao topo estratégico. A análise de dados baseou-se na triangulação entre técnicas de análise qualitativa e quantitativa, com particular incidência para a análise factorial de correspondências múltiplas e para a análise classificatória. Esta estratégia metodológica responde à perspectiva de análise relacional que se adoptou, a qual permite interpretar, de forma exploratória e numa óptica de diferenciação, as estruturas latentes que caracterizam as relações entre variáveis intervenientes no processo de construção social das competências profissionais. 


\section{As MOdALIDADES DE GESTÃo DE COMPETÊNCIAS}

Para a reflexão sobre as diferentes modalidades de gestão de competências, centramos a análise nas grandes tendências que caracterizam a forma como as empresas produzem, gerem e reconhecem os saberes, e mobilizam as competências dos trabalhadores do núcleo operacional. A partir da análise factorial de correspondências múltiplas e da análise classificatória, definiram-se quatro perfis de trabalhadores configurados segundo os modelos organizacionais e gestionários de apropriação do conteúdo cognitivo das actividades de trabalho em cada um dos domínios de tarefas estudados.

O quadro 1 apresenta esquematicamente uma sinopse comparativa entre os perfis de trabalhadores sinteticamente definidos para as duas empresas. A sua análise deve ser acompanhada da leitura do texto que a seguir se expõe acerca das modalidades de gestão das competências na Lume e na Hame ${ }^{22}$.

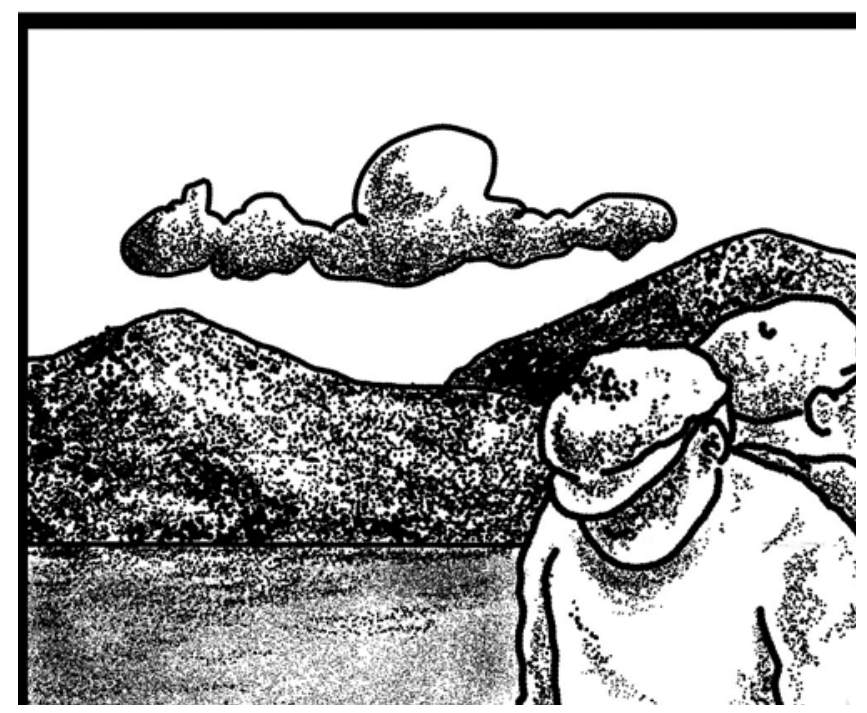

\section{QUADRo 1}

A construção social das competências profissionais por perfis de trabalhadores ${ }^{a}$

\begin{tabular}{|c|c|c|c|c|}
\hline Perfis de trabalhadores & Perfil 2 & Perfil 4 & Perfil 1 & Perfil 3 \\
\hline Empresas & \multicolumn{2}{|c|}{ Lume } & \multicolumn{2}{|c|}{ Hame } \\
\hline Domínio de tarefas & Maquinação & Montagem & Maquinação & Montagem \\
\hline $\begin{array}{l}\text { Organização da } \\
\text { actividade de } \\
\text { trabalho }\end{array}$ & $\begin{array}{l}\text { Exercida num posto } \\
\text { de trabalho individual } \\
\text { e com um conteúdo } \\
\text { diversificado }\end{array}$ & $\begin{array}{l}\text { Exercida em linha com } \\
\text { um conteúdo invariável }\end{array}$ & $\begin{array}{l}\text { Exercida em equipas } \\
\text { semi-autónomas e } \\
\text { com um conteúdo } \\
\text { diversificado }\end{array}$ & $\begin{array}{l}\text { Exercida em equipas } \\
\text { semi-autónomas e com } \\
\text { conteúdo pouco } \\
\text { diversificado }\end{array}$ \\
\hline $\begin{array}{l}\text { Modelos de gestão } \\
\text { directa }\end{array}$ & Modelo híbrido & $\begin{array}{l}\text { Modelo rígido; } \\
\text { modelo híbrido }\end{array}$ & Modelo flexível & $\begin{array}{l}\text { Modelo flexível; } \\
\text { modelo híbrido }\end{array}$ \\
\hline $\begin{array}{l}\text { Conteúdos das } \\
\text { competências: } \\
\text { - técnicas } \\
\text { - estratégicas }\end{array}$ & $\begin{array}{l}\text { Alargadas e } \\
\text { multivalentes } \\
\text { Independência, } \\
\text { auto-controlo e } \\
\text { autonomia } \\
\text { Escassas }\end{array}$ & $\begin{array}{l}\text { Restritas e } \\
\text { especializadas } \\
\text { Ausentes } \\
\text { Escassas }\end{array}$ & $\begin{array}{l}\text { Alargadas e } \\
\text { multivalentes } \\
\text { Independência, } \\
\text { auto-controlo e } \\
\text { autonomia } \\
\text { Intensas }\end{array}$ & $\begin{array}{l}\text { Restritas e } \\
\text { multivalentes } \\
\text { Subordinação moderada, } \\
\text { auto-controlo e } \\
\text { autonomia parcial } \\
\text { Moderadas }\end{array}$ \\
\hline $\begin{array}{l}\text { Aprendizagem } \\
\text { individual } \\
\text { Práticas } \\
\text { organizacionais de } \\
\text { aprendizagem }\end{array}$ & $\begin{array}{l}\text { Envolvimento } \\
\text { regular }\end{array}$ & $\begin{array}{l}\text { Pela prática; } \\
\text { ausência de } \\
\text { aprendizagem } \\
\text { Envolvimento pontual } \\
\text { e exclusão }\end{array}$ & $\begin{array}{l}\text { Reflexiva; pela prática } \\
\text { Aprendizagem decorrente } \\
\text { de mudanças processuais } \\
\text { Envolvimento intenso }\end{array}$ & $\begin{array}{l}\text { Envolvimento } \\
\text { intenso }\end{array}$ \\
\hline $\begin{array}{l}\text { Trajectórias } \\
\text { profissionais }\end{array}$ & Bloqueada & $\begin{array}{l}\text { Ascensional } \\
\text { retardada }\end{array}$ & $\begin{array}{l}\text { Ascensional progressiva. } \\
\text { Em continuidade com } \\
\text { trajectória externa }\end{array}$ & $\begin{array}{l}\text { Não evolutiva } \\
\text { contingente }\end{array}$ \\
\hline $\begin{array}{l}\text { Trajectórias } \\
\text { formativas }\end{array}$ & $\begin{array}{l}\text { Diversificada e } \\
\text { reincidente }\end{array}$ & De acolhimento rápido & De inserção longa & $\begin{array}{l}\text { De iniciação ao } \\
\text { trabalho }\end{array}$ \\
\hline
\end{tabular}




\begin{tabular}{|l|l|l|l|l}
$\begin{array}{l}\text { Lógicas de } \\
\text { aprendizagem e } \\
\text { avaliação da formação }\end{array}$ & $\begin{array}{l}\text { Lógica formal da } \\
\text { aprendizagem com } \\
\text { expectativas de } \\
\text { continuidade dos } \\
\text { trajectos formativos }\end{array}$ & $\begin{array}{l}\text { Lógica hierárquica da } \\
\text { aprendizagem sem } \\
\text { expectativas formativas; } \\
\text { lógica informal da } \\
\text { aprendizagem com } \\
\text { expectativas de adaptação } \\
\text { dos saberes pela formação }\end{array}$ & $\begin{array}{l}\text { Lógica formal e } \\
\text { substancialista da } \\
\text { aprendizagem com } \\
\text { expectativas de } \\
\text { continuidade dos } \\
\text { trajectos formativos }\end{array}$ & $\begin{array}{l}\text { Lógica informal } \\
\text { da aprendizagem } \\
\text { com expectativas de } \\
\text { valorização pessoal pela } \\
\text { formação }\end{array}$ \\
$\begin{array}{l}\text { Auto-conceito do } \\
\text { desempenho } \\
\text { laboral }\end{array}$ & $\begin{array}{l}\text { Positivo, centrado no baseado no } \\
\text { potencial de saberes } \\
\text { detidos; negativo, } \\
\text { limitado aos saberes } \\
\text { usados }\end{array}$ & $\begin{array}{l}\text { Positivo entre saberes } \\
\text { detidos e utilizados; } \\
\text { negativo, limitado ao } \\
\text { saberes usados } \\
\text { Avotencial de saberes } \\
\text { detidos }\end{array}$ & $\begin{array}{l}\text { Positivo centrado no } \\
\text { desvio entre saberes } \\
\text { detidos e usados }\end{array}$ \\
\hline $\begin{array}{l}\text { Avaliaçããa da negativa } \\
\text { integração } \\
\text { profissional }\end{array}$ & Fegativa & Avaliação positiva & Avaliação ambivalente \\
\hline Sexo & Feminino & Feminino & Masculino & Feminino \\
\hline Antiguidade média & 8.3 & 7.2 & 4.9 & 3.4 \\
\hline
\end{tabular}

O grafismo em itálico refere-se a perfis parciais temáticos não diferenciadores estatisticamente do perfil de trabalhadores, porém significativos do ponto de vista da sua caracterização sociológica.

\subsection{Uma lógica de utilização dos saberes - a gestão dos empregos pelo modelo de qualificação na Lume}

A gestão organizacional de pendor tecnocêntrico (KOVÁCS, 1998b; 1998c ${ }^{23}$ do quotidiano de trabalho na Lume assenta numa estrutura organizacional do tipo burocracia mecanicista (MINTZBERG, 1995) ${ }^{24}$. Essa opção organizacional decorre do domínio de tarefas da montagem constituir a actividade central da empresa, com predominância de mão-de-obra feminina. Tais características, associadas à elevada dimensão e antiguidade da empresa, facilitam a estandardização do trabalho com efeitos de rigidificação desfavoráveis quer às incertezas que surgem nos processos produtivos, quer às oportunidades de aprendizagem dos trabalhadores do núcleo operacional. Pautada por: (i) fundamentos mecânicos e especializados da organização do trabalho, (ii) práticas de gestão imediatista e utilitarista dos $\mathrm{RH}$, bem como (iii) modelos de gestão directa tendencialmente híbridos (entre os modelos rígidos e os flexíveis), apresenta uma estratégia de utilização dos saberes de acordo com as necessidades da empresa e, consequentemente, assente no modelo da qualificação. As competências são equiparadas aos saberes-fazer de execução necessários à ocupação de um posto de trabalho específico. A lógica da qualificação do posto ou do emprego, alicerçada em pressupostos técnico-económicos, sobrepõe-se à qualificação dos trabalhadores. Gerem-se os empregos (não as competências) de acordo com uma lógica economicista que acentua, no domínio organizacional e gestionário, a segmentação dos trabalhadores, estruturada com base na natureza diferenciada do conteúdo cognitivo das actividades de trabalho.

Atendamos aos dois perfis de trabalhadores em questão.

Centremos, em primeiro lugar, a análise no segmento de traba- lhadores do domínio de tarefas da maquinação (perfil 2) integrados em trajectórias profissionais bloqueadas e de aprendizagem lata e regular de qualificações transferíveis. O conteúdo complexo das actividades de trabalho desenvolvidas no domínio de tarefas da maquinação implica o accionamento de competências técnicas alargadas e multivalentes, e de competências estratégicas caracterizadas pela independência, pelo auto-controlo e pela autonomia nas acções correctivas desenvolvidas. Esse tipo de competências é fortemente condicionado pelas características do processo tecnológico da maquinação ${ }^{25}$, bem como pelas exigências de optimização do mesmo por via do desempenho laboral enriquecido dos trabalhadores. As competências relacionais mobilizadas por esses trabalhadores são escassas. Estas saem fortemente penalizadas, particularmente no domínio da cooperação, pelo modelo de organização do trabalho, que impõe um exercício do trabalho isolado num posto individual, e pelo modelo de gestão híbrido a que os trabalhadores estão sujeitos, o qual admite algum tipo de participação e de comunicação de carácter estritamente formal e de acordo com regulamentações bem definidas, mas limita as relações interpessoais dos trabalhadores em benefício das relações que estes têm o dever de estabelecer com os detentores formais da autoridade (responsáveis directos e seus assessores). Assim, também o envolvimento desses trabalhadores em práticas organizacionais de aprendizagem é moderado, acabando estes por se distinguir dos outros perfis de trabalhadores pela negativa, ao serem os únicos que, por exemplo, não dialogam com os pares no decurso do trabalho.

Estes trabalhadores diferenciam-se por atribuírem uma importância idêntica à aprendizagem pela experiência de trabalho e à aprendizagem pela formação profissional como formas de aquisição dos saberes necessários ao desempenho profissional. 
No mesmo sentido, a concepção de aprendizagem reflexiva distingue-os ao afirmarem aprender continuamente com o seu desempenho laboral, dada a oportunidade que representam para aprofundarem os seus saberes, para perceberem a razão de ser dos processos de execução e de reflectirem acerca das perturbações. Para a importância atribuída à formação profissional e para a concepção de aprendizagem reflexiva pela prática laboral terá contribuído o seu intenso contacto com práticas de formação profissional, em que a transmissão e a aprendizagem de conteúdos teóricos e procedimentais os terá socializado com as vias simbólicas de aquisição de saberes e terá treinado as actividades cognitivas de formalização (MALGLAIVE, $1995)^{26}$. Apresentam trajectórias formativas marcadas pela frequência de várias acções de formação, sobretudo de curta ou ultra-curta duração, diversificadas em termos das áreas e dos objectivos. A formação profissional frequentada reveste-se de objectivos de aprendizagem, contribuindo, concretamente, para o desenvolvimento de capacidades de trabalho antropocêntricas (tais como as capacidades de resolução de problemas e de levar a cabo novas tarefas, e as capacidades de relacionamento e discussão acerca de problemas). Dentro dessa lógica formal e substancialista da aprendizagem perspectivam prosseguir a sua trajectória formativa.

As suas trajectórias bloqueadas caracterizam-se por percursos ascensionais, actualmente maduros, em que os trabalhadores já atingiram o topo da hierarquia operária após uma inserção que ronda os 8,3 anos de antiguidade média na empresa, não dispondo agora de alternativas de evolução. Trata-se de uma trajectória qualificada, de titular de topo, contratualmente não precária, mas cujo potencial de progressão no futuro é nulo. A única dimensão não vedada à progressão é a dimensão remuneratória e, apesar de auferirem os mais elevados salários de base da Lume, a que se soma uma retribuição bi-anual indexada ao desempenho empresarial (que, contudo, não assume um carácter de excepção na empresa), os seus rendimentos do trabalho não são alvo de qualquer tipo de reconhecimento social retributivo, isto é, não têm acesso a benefícios sociais ou a complementos de remuneração. As suas trajectórias reflectem uma lógica funcionalista de gestão dos RH, em concordância com os princípios contratuais legais estabelecidos e sem mostras de preocupação com a sua adaptação às necessidades e expectativas socioprofissionais desses indivíduos.

No seio dessa trajectória manifesta-se uma conflitualidade em termos do auto-conceito. Cerca de metade desses trabalhadores revela um auto-conceito positivo baseado no potencial de conhecimentos detidos, tal como verificaremos para os trabalhadores homólogos da Hame. Seguros e confiantes dos seus saberes e nas suas capacidades, mostram-se capazes de aceitar novos desafios na ocupação de um qualquer posto de trabalho. Os restantes manifestam um auto-conceito negativo, limitado pelos conhecimentos restritos utilizados na sua actividade de trabalho e pelas capacidades redutoras (tais como, as capacidades de executar tarefas simples e repetitivas, e de trabalhar sozinho) exigidas para o seu desempenho. Esses trabalhadores, pouco confiantes nos seus saberes e nas suas capacidades, não se consideram aptos a ocupar senão postos de trabalho idênticos aos agora ocupados, ou outros, desde que integrados na mesma unidade funcional de pertença. Consideram os seus saberes adequados às funções que desempenham, as quais apresentam um conteúdo limitado e restrito, pelo que avaliam desfavoravelmente o potencial de saberes e capacidades por si detidos.

Ao invés do auto-conceito, objecto de uma apreciação ambivalente, a avaliação negativa da integração profissional é partilhada por todos os trabalhadores. Com efeito, revelam-se globalmente insatisfeitos, assumindo fundamentalmente relevo a dimensão extrínseca do trabalho. Denunciam a ausência de reconhecimento de que são genericamente alvo e distinguem-se por salientarem a injustiça salarial. A sua pertença à empresa é considerada irrelevante em termos identitários.

Analisemos agora o perfil dos trabalhadores inseridos no domínio de tarefas da montagem (perfil 4), caracterizados por percursos não-qualificados de estagnação ou mesmo de regressão da aprendizagem. Os trabalhadores em causa desenvolvem uma actividade de trabalho de conteúdo simples e repetitivo, o que, associado a um desempenho num posto individual, integrado numa organização do trabalho em linha, acentua a natureza empobrecedora do trabalho. Esta operacionaliza-se num exercício de competências técnicas restritas e especializadas, numa ausência de competências estratégicas e numa mobilização escassa de competências relacionais. Para o conteúdo limitado assumido pela competências estratégicas e relacionais muito contribuem os modelos de organização parcelar do trabalho e os modelos de

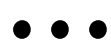

$$
\begin{aligned}
& \text { seu desempenho laboral, } \\
& \text { dada a oportunidade } \\
& \text { que representam para } \\
& \text { aprofundarem os seus } \\
& \text { saberes, para perceberem a } \\
& \text { razão de ser dos processos } \\
& \text { de execução e de reflectirem } \\
& \text { acerca das perturbaçoes. }
\end{aligned}
$$


gestão rígidos a que estão subordinados, que lhes impõem uma consulta dos responsáveis directos antes de qualquer intervenção menos rotineira, bem como um controlo intenso do trabalho e uma disciplina comportamental que dificultam a entre-ajuda e mesmo a interacção entre colegas.

A aprendizagem contínua pelo desempenho laboral assume uma concepção prática para mais de metade desses trabalhadores. Os restantes consideram não decorrer da actividade quotidiana de trabalho ou da resolução de perturbações qualquer oportunidade de aprendizagem.

No domínio formativo, os seus percursos de acolhimento rápido com vistas a uma adaptação estrita às necessidades do processo produtivo são marcados por acções de formação de muito curta duração, que visam a transmissão e a consequente adopção de práticas de trabalho, nos domínios da qualidade e comportamental, adequadas ao cumprimento dos normativos básicos de montagem dos produtos.

Do ponto de vista das lógicas de aprendizagem e de avaliação da formação profissional, distinguem-se por privilegiarem a aprendizagem com os responsáveis hierárquicos, por considerarem que não frequentaram acções de formação, bem como por não terem quaisquer expectativas formativas futuras. Também a lógica informal da aprendizagem, nomeadamente pela rotação entre postos de trabalho, com expectativas de adaptação dos saberes, adquire alguma relevância entre esses trabalhadores, apesar de não assumir um poder distintivo.

Uma outra fragmentação interna nesse grupo de trabalhadores manifesta-se no âmbito das práticas organizacionais de aprendizagem. Ainda que a maior parte esteja só pontualmente envolvida em condições organizacionais e gestionárias favoráveis aos processos de aprendizagem, distingue-se por se integrar nesse perfil a totalidade dos trabalhadores que se encontra excluído das mesmas. Está-se, assim, perante o perfil de trabalhadores pior posicionado em termos do seu envolvimento em práticas organizacionais favoráveis à aprendizagem.

As suas trajectórias profissionais ascensionais retardadas destacam-se por apresentarem uma vertente evolutiva contratual, salarial e de carreira, conquistada de forma muito dilatada no tempo. Ascendendo lentamente na carreira, bem como nos respectivos níveis salariais, gozam actualmente de uma situação de estabilidade contratual, manifestando percursos amadurecidos e estáveis, sem possibilidades ou com parcas possibilidades de progressão no futuro. É uma trajectória não qualificada, apenas reconhecida remuneratoriamente de forma esporádica na vertente do desempenho empresarial. Reflecte as práticas de gestão dos RH imediatistas, que procuram retirar todos os benefícios do enquadramento sectorial legal, sem qualquer esforço de adaptação às características da empresa ou às necessidades e expectativas dos seus trabalhadores.

Uma outra ambivalência manifesta-se no auto-conceito do desempenho laboral. Distribuem-se entre (i) um auto-conceito positivo, centrado no diferencial entre saberes detidos e utilizados, e na possibilidade de utilização dos primeiros no desempenho de outras funções noutras unidades funcionais e (ii) um autoconceito negativo, limitado aos saberes restritos utilizados na

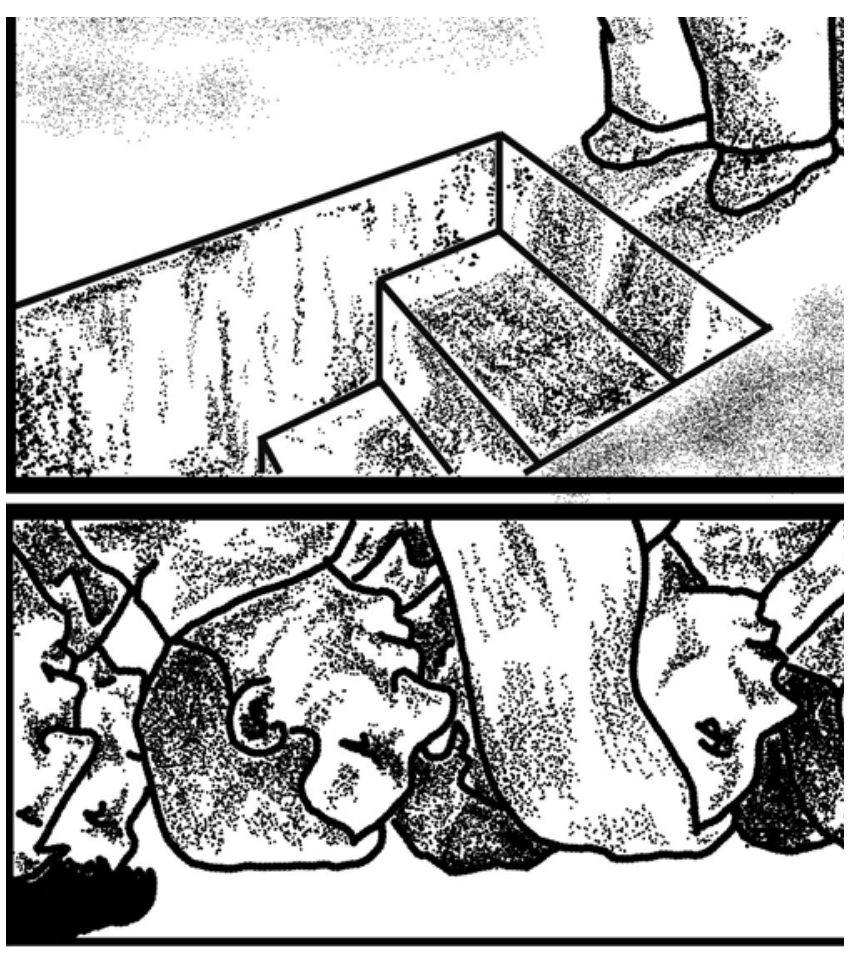

ocupação actual, não transferíveis para outros postos a não ser que se trate de postos semelhantes no seio da unidade funcional de pertença.

Finalmente, tal como os seus colegas de trabalho integrados no domínio de tarefas da maquinação, avaliam negativamente a sua integração profissional. Sentem-se globalmente insatisfeitos com o trabalho, não se sentem reconhecidos e distinguem-se por se sentirem injustiçados salarialmente. A pertença à empresa não assume qualquer significado identitário.

\subsection{Uma lógica de gestão das competências - a gestão das pessoas pelo modelo de competências na Hame}

A gestão organizacional de pendor antropocêntrico (KOVÁCS, 1998b; 1998c) ${ }^{27}$ do quotidiano de trabalho na Hame assenta numa estrutura organizacional do tipo burocracia profissional (MINTZBERG, 1995) ${ }^{28}$. Essa opção organizacional decorre da actividade central da empresa ser constituída pelo domínio de tarefas da maquinação, cuja natureza complexa do conteúdo cognitivo do trabalho determina a importância estratégica do núcleo operacional para os desempenhos empresariais. Pautada por (i) fundamentos orgânicos e sociotécnicos da organização do trabalho, (ii) práticas de gestão desenvolvimentista e estratégica dos RH e (iii) modelos de gestão directa tendencialmente flexíveis, opta por uma estratégia de utilização e de desenvolvimento das competências como base do desempenho empresarial. As competências são usadas de forma instrumental pela estratégia empresarial, tendo-se em conta, para os segmentos de trabalhadores estratégicos, as suas aspirações, o sentido que atribuem ao trabalho, as suas perspectivas profissionais, o reconhecimento a 


\section{Essa vivência laboral resulta}

\author{
num auto-conceito positivo, \\ baseado no potencial de saberes \\ detidos por via da formação \\ profissional e da própria \\ aprendizagem continua pelo \\ desempenho laboral.
}

que legitimamente aspiram e, paralelamente, as necessidades de filiação e coesão social (ZARIFIAN, 2002a) ${ }^{29}$.

Todavia, não se trata de uma verdadeira lógica de gestão das competências, mas de uma modalidade de gestão aproximada do respectivo tipo ideal. Entre os desvios que pudemos apurar empiricamente destaca-se a parca propensão para a capitalização de saberes detidos pelos trabalhadores. De facto, com excepção de quatro trabalhadores que apresentam trajectórias ascensionais progressivas, as quais parecem surgir na continuidade de trajectórias profissionais externas qualificadas, não se detecta qualquer outro padrão de relacionamento entre saberes detidos via aprendizagem formal ou informal e a sua mobilização em competências na empresa. Por outro lado, as práticas de gestão dos RH da Hame não são suficientemente integradas e coerentes, tendo subjacentes distinções, de acordo com a inserção dos trabalhadores nos dois domínios de tarefas em análise.Vejamos:

Os trabalhadores do domínio de tarefas da maquinação (perfil 1) afectos a trajectórias profissionais evolutivas e de aprendizagem lata e intensa de competências transferíveis e reconhecidas. Esse tipo de trajectória diz respeito unicamente a trabalhadores do sexo masculino, cujas actividades de trabalho implicam um grau de complexidade técnica que, no seio de um modelo de organização do trabalho baseado em equipas semi-autónomas e numa atribuição de funções não apenas individuais, mas igualmente colectivas, se traduz num exercício laboral enriquecido. Este pauta-se por competências técnicas alargadas a várias acções técnicas de trabalho, desenvolvidas de forma multivalente, por competências estratégicas caracterizadas pela independência das acções, um intenso auto-controlo e uma autonomia nas acções correctivas desenvolvidas, bem como por competências relacionais intensas nos domínios cooperativo, participativo e comunicacional.

São trabalhadores que, no domínio das condições organizacionais e gestionárias da aprendizagem, se encontram intensamente envolvidos em práticas favoráveis à aprendizagem por cooperarem, dialogando, discutindo, ensinando e resolvendo problemas com e aos colegas de trabalho, por participarem, com os responsáveis directos, na regulação quotidiana das células de maquinação a que pertencem e por terem acesso e fazerem uso de diversos tipos de informação disponível nas células produtivas e na empresa. Essas práticas são corolário de modelos de gestão directa flexíveis, mais orientados para o controlo da dinâmica do desempenho grupal do que para os desempenhos individuais.

Apresentam trajectórias ascensionais progressivas que reflectem práticas de gestão dos RH reconhecedoras do lugar estratégico por eles ocupado no seio da divisão técnica do trabalho. Caracterizam-se por apresentarem desempenhos laborais qualificados, evolutivos em termos da carreira operária e com potencial de progressão futura. Contratual e salarialmente não-precária, esse tipo de trajectória é remuneratoriamente reconhecida na dupla vertente do desempenho empresarial e das recompensas sociais.

As trajectórias formativas de inserção longa assentam numa transmissão aprofundada e desenvolvida de saberes na área técnica na fase inicial de integração na empresa. Tal percurso formativo prossegue, sustentado por acções de mais curta duração que garantem uma actualização restrita dos saberes, frequentemente em áreas técnicas diferentes das já dominadas mas complementares às primeiras, na medida em que aquelas constituem um alicerce básico para o exercício laboral no domínio de tarefas da maquinação.

Esse tipo de inserção laboral e formativa justifica que os trabalhadores privilegiem uma concepção formal de aprendizagem e projectem continuar o seu percurso formativo, o qual assume, primordialmente, objectivos de aprendizagem, mais concretamente orientados para o incremento de capacidades de trabalho antropocêntricas (tais como capacidades de resolver problemas e de fazer tarefas novas, capacidades de relacionamento e de discussão dos problemas).

Porém, as concepções desses trabalhadores acerca da aprendizagem contínua pelo desempenho laboral não são consensuais. Distribuem-se entre os que consideram que aprendem pela prática, valorizando a experiência, e os que conferem primazia a uma aprendizagem reflexiva. Singular e comum a todos os trabalhadores desse perfil é o facto de as situações de mudança no processo técnico e no produto se terem constituído como oportunidades de aprendizagem.

Essa vivência laboral resulta num auto-conceito positivo, baseado no potencial de saberes detidos por via da formação profissional e da própria aprendizagem contínua pelo desempenho laboral. Apresentam-se confiantes e seguros das suas reais e potenciais capacidades de intervenção laboral, designadamente da capacidade de resolução de problemas, avaliando de forma positiva a sua inserção profissional. Sentem-se francamente satisfeitos com o trabalho, fundamentalmente com a sua dimensão extrínseca. Consideram-se reconhecidos pelos modelos de gestão da empresa, quer ao nível remuneratório, quer da carreira, quer em termos da sua evolução genérica no interior da empresa. Compreende-se que a empresa constitua para eles um importante referencial identitário.

A esse perfil de trabalhadores opõe-se as trabalhadoras do domínio de tarefas da montagem (perfil 3), afectas a trajectórias 
profissionais contingentes e de aprendizagem de saberes substituíveis. O conteúdo técnico simplificado e pouco diversificado das actividades de trabalho dessas trabalhadoras é atenuado em termos dos seus efeitos empobrecedores ao ser exercido em equipas de trabalho semi-autónomas. Isto reflecte-se num alargamento das actividades de trabalho de cada trabalhadora, que executa todas as acções técnicas de trabalho no seio das célula produtiva de pertença, garantindo, ainda que com menor frequência, outro tipo de acções técnicas de trabalho, de natureza idêntica, noutras células produtivas do mesmo domínio de tarefas. Desse modo, as suas competências técnicas, apesar de restritas porque limitadas a acções de execução e de controlo da execução, são multivalentes. As competências estratégias pautam-se pelo controlo exercido pelas trabalhadoras sobre o desenrolar do seu próprio desempenho, por uma subordinação moderada aos responsáveis directos, resultado de modelos de gestão híbridos, tendencialmente flexíveis, mas que impõem algumas restrições nas tomadas de decisões. Daqui resulta também uma autonomia parcial nas acções correctivas implementadas, explicada igualmente pelo predomínio de um modelo partilhado de resolução das perturbações em equipa. A equipa, enquanto unidade elementar de trabalho da Hame, explica, igualmente, uma mobilização moderada de competências relacionais, fundamentalmente no domínio comunicacional, particularmente marcadas pelo intenso diálogo entre pares, mas também nos domínios cooperativo e de participação.

Tal como os seus colegas integrados no domínio de tarefas da maquinação, encontram-se intensamente envolvidas em práticas organizacionais favoráveis à aprendizagem, sendo, todavia, menos ouvidas e auscultadas pelos responsáveis directos na regulação quotidiana das células produtivas, o que decorre quer dos modelos de gestão imperantes, tendencialmente menos flexíveis (mais híbridos), quer do próprio lugar ocupado pelas trabalhadoras na divisão técnica do trabalho na empresa que, não assumindo um carácter central para o negócio da empresa, tende a ser quotidianamente menos valorizado.

Essas trabalhadoras partilham de uma concepção de aprendizagem pela prática. Face à frequência escassa de acções de formação de ultra-curta duração que tiveram como objectivo garantir uma integração imediata na actividade de trabalho, valorizam a aquisição de saberes pela experiência de trabalho. Destacam na sua aprendizagem o ensino baseado em interacções pouco formais, particularmente nas interacções com os colegas de trabalho e na colaboração de toda a equipa. Consequentemente, tendem a valorizar uma lógica informal da aprendizagem, o que não exclui as expectativas de se valorizarem pessoalmente por via da frequência futura de acções de formação.

Em sintonia com estas intenções formativas encontra-se a manifestação de um auto-conceito positivo centrado no diferencial entre saberes detidos e utilizados. Consideram que os primeiros são superiores aos segundos e auto-avaliam-se preparadas para o desempenho de outras funções noutras células produtivas, particularmente se estas forem adaptadas aos saberes detidos e não mobilizados na actualidade, isto é, à sua formação escolar ou profissional, ou desde que, para o efeito, lhes fosse proporcionada formação. Esse tipo de avaliação do potencial associado às expectativas formativas aponta para trabalhadoras confiantes nos seus saberes e nas suas capacidades, trabalhadoras não desencorajadas, apesar da fraca mobilização dos saberes detidos, decorrente de um conteúdo de trabalho relativamente empobrecedor que, não obstante, lhes exige o accionamento de um tipo de capacidades não completamente desprovidas de empenho e brio pessoal, tais como as capacidades de organização e de resolução de problemas.

Essas trabalhadoras constituem o núcleo flexível de mãode-obra da Hame, estando as suas trajectórias profissionais não evolutivas contingentes dependentes das oscilações do negócio da empresa. Afectas a um desempenho laboral não-qualificado, essa dependência resulta na integração numa carreira de ajudante (e não de titular) e numa instabilidade contratual associada a uma inserção profissional relativamente curta ( 3,4 anos em média) na Hame. A dimensão retributiva é a única que atenua o carácter desfavorável das suas trajectórias profissionais, quer ao nível da remuneração individual (em que auferem um salário superior ao definido pelo contrato colectivo de trabalho), quer no domínio da remuneração colectiva (trajectórias remuneratoriamente reconhecidas, ainda que mais na vertente social do que na do desempenho empresarial, isto é, as trabalhadoras beneficiam de recompensas sociais e de complementos de remuneração, bem como de uma retribuição anual pelo desempenho empresarial, mas estão excluídas do prémio de mérito colectivo a que acedem os trabalhadores integrados no domínio de tarefas da maquinação).

Por força dessa vivência profissional e formativa, as trabalhadoras manifestam alguma ambivalência na avaliação que fazem da sua integração profissional. Sentem-se medianamente satisfeitas com os diferentes aspectos que envolvem o seu trabalho, pese embora manifestem sentimentos contraditórios reveladores de incertezas no que se refere ao reconhecimento de que são alvo e aos factores de pertença identitária.

\section{SOBRE AS DETERMINANTES EMPRESARIAIS NA CONSTRUÇÃO SOCIAL DAS COMPETÊNCIAS PROFISSIONAIS}

A interrogação principal colocada foi a de perceber os padrões de relações que, no seio das empresas, se estabeleciam entre as práticas de mudança organizacional, a aprendizagem de saberes e a mobilização de competências dos trabalhadores do núcleo operacional, de forma a compreender as diferentes modalidades de gestão de competências. De acordo com o quadro teorico-metodológico sinteticamente exposto, a interrogação enunciada dá conta do que se designou ser a construção social das competências profissionais no campo económico.

A análise privilegiou os contextos de mudança organizacional. Concluído o estudo, infirma-se a hipótese de estes se constituírem como oportunidades privilegiadas de aprendizagem. A relevância numérica do perfil de mudanças organizacionais sem repercussões no domínio da aprendizagem conduz a admitir que as mesmas não se configuram como situações de aprendizagem 
e que o único tipo de mudança que emerge, enquanto situação de aprendizagem, é a mudança processual decorrente quer de alterações tecnológicas introduzidas no processo, quer de novas exigências de qualidade e de produtividade no produto. Os processos de mudança organizacional analisados, frequentemente inspirados nas estratégias japonesas de melhoramento contínuo do processo com o envolvimento de todos os trabalhadores, não contribuem para a difusão e implementação de novas práticas no âmbito do conteúdo cognitivo do trabalho produtivo, a favor dos trabalhadores do núcleo operacional.

$\mathrm{Na}$ linha de outros trabalhos ${ }^{30}$, verifica-se que a mobilização da inteligência operária, pela abertura ao diálogo e às sugestões dos trabalhadores, bem como pela audição dos trabalhadores e participação nos diferentes projectos de melhoria contínua, impõe, particularmente, um envolvimento responsável dos trabalhadores e o incremento dos resultados do seu desempenho. Para além dessas consequências, as duas empresas manifestam perspectivas diferentes no que se refere aos princípios subjacentes à mudança organizacional: na Lume, as pequenas melhorias organizacionais introduzidas (alteração do layout, da sequência das operações de trabalho, dos componentes e equipamentos técnicos que manuseiam), uma vez testadas, dão origem a práticas de estandardização de procedimentos, à normalização e à rotinização de tarefas, dando lugar a uma continuidade com os princípios da OCT; na Hame, porque aquelas práticas não constituem apenas projectos pontuais de mudança organizacional, integrando-se num modelo de organização do trabalho em equipa e numa estratégia de fragmentação da fábrica em centros

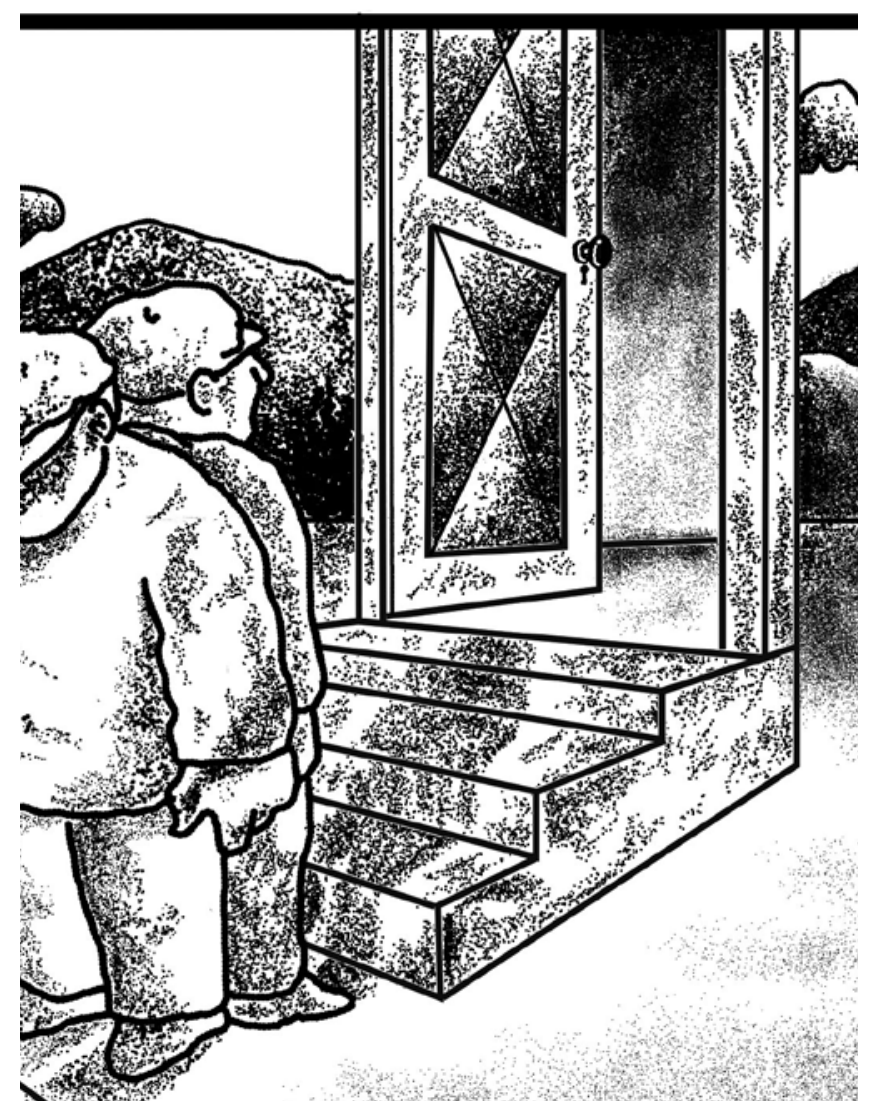

de custos autónomos e respectivas alterações em termos dos modelos hierárquicos de controlo e de subordinação, permitem que se estabeleça alguma forma de interligação entre o esforço dos RH, o processo de produção e os resultados obtidos. Porém, os trabalhadores não relacionam essas mudanças com um processo de aprendizagem. Apenas as mudanças processuais são apontadas pelos trabalhadores que exercem a sua actividade no domínio de tarefas da maquinação como tendo impactos formativos (perfil 4, quadro 1). Segundo esses trabalhadores, as mudanças introduzidas no processo e no produto carecem de novos saberes na área técnica. Os níveis de complexidade, diversidade, independência/autonomia e responsabilidade no trabalho tornaram-se mais exigentes. $\mathrm{O}$ ritmo de trabalho não se intensifica, havendo mesmo uma diminuição do mesmo. Configuram, assim, mudanças que têm implicações em termos da aprendizagem dos trabalhadores, ao darem origem a novas necessidades de formação e à consequente frequência da mesma, o que justifica que não tenham desencadeado qualquer dificuldade de adaptação por parte dos trabalhadores.

A análise comparativa entre as duas empresas postas em confronto salienta a importância determinante dos conteúdos cognitivos das actividades de trabalho dos domínios de tarefas da maquinação e da montagem na produção de saberes e na mobilização de competências. Estes justapõem-se, em termos explicativos, a outras dimensões caracterizadoras das empresas, no que se refere às competências mobilizadas pelos trabalhadores na actividade de trabalho e às trajectórias profissionais e formativas. Isto significa, pois, que o lugar ocupado na divisão técnica do trabalho tem um efeito diferenciador entre trabalhadores, sendo que as configurações organizacionais e gestionárias assumidas no interior das empresas fazem sentir a sua influência mediada por esse lugar, a que corresponde, no quadro de leitura utilizado para a análise das competências, um conteúdo cognitivo da actividade de trabalho.

Ora, a pertença dos trabalhadores a uma empresa particular enquanto elemento estruturante de configurações organizacionais e gestionárias próprias era considerada, a título de hipótese teórica, o principal elemento distintivo das modalidades assumidas pelos processos de produção de saberes e de mobilização de competências. Porém, constatou-se que a empresa tem menos peso na definição dos perfis finais do que a pertença dos sujeitos a um determinado domínio de tarefas. Os trabalhadores da Lume e da Hame que exercem actividades de trabalho no domínio da maquinação aproximam-se entre si, diferenciando-se nitidamente dos que exercem actividades no domínio de tarefas da montagem. Desse modo, somos conduzidos a afirmar que a construção social das competências profissionais é diferente, de acordo com os dois grandes segmentos que integram o mercado interno de trabalho das duas empresas: o segmento de trabalhadores da maquinação, que integra os perfis 1 e 2 (quadro 1), e corresponde aos mercados profissionais de qualificações transferíveis (MARSDEN, 1989) ${ }^{31}$, ambos associados ao segmento primário dos mercados internos de trabalho (DOERINGER; PIORE, 1985 ${ }^{32}$; o segmento dos trabalhadores da montagem, que integra os perfis 3 e 4 (quadro 1), e corresponde aos mercados 
de trabalho não qualificados e ocasionais (MARSDEN, 1989) ${ }^{33}$, e representa o segmento secundário dos mercados internos de trabalho (DOERINGER; PIORE, 1985) ${ }^{34}$.

Essa estruturação do processo de construção social das competências, a partir de uma variável eminentemente tecnológica, integrante da natureza mais ou menos complexa ou simples das actividades de trabalho, em nada determina as modalidades organizacionais e gestionárias de sua apropriação. Recusa-se, assim, qualquer perspectiva de determinismo tecnológico, tanto mais que, globalmente nas duas empresas, as condicionantes tecnológicas se revelam semelhantes no que diz respeito às características do sistema de produção: sistema técnico convencional, não sofisticado tecnologicamente e intensivo em RH; processos produtivos compostos por operações unitárias estandardizadas, orientados para a fabricação de produtos especializados, ainda que diversificados, em pequenas e médias séries.

A forte estruturação delineada a partir do domínio de tarefas associa-se, em cada uma das empresas, a uma apropriação organizacional e gestionária singular. Esta resulta, por um lado, em diferenciações manifestas nas práticas de desempenho laboral e nas trajectórias profissionais e formativas, e, por outro, numa vivência e numa atribuição de sentido distintas, segundo quer as experiências de trabalho e de aprendizagem, quer uma trajectória de vida mais lata subjectivamente experimentada pelos sujeitos.

Ponderadas as diferentes determinações, conclui-se que os espaços de trabalho constituem ora espaços de aprendizagem, ora de estagnação e regressão de saberes, segundo a natureza do conteúdo cognitivo das actividades de trabalho e as configurações organizacionais e gestionárias, variáveis que apresentam padrões de inter-relacionamento diferenciados entre empresas e entre domínios de tarefas. Vale a pena aprofundar as singularidades desta constatação.

No que se refere aos trabalhadores integrados no domínio de tarefas da maquinação, a análise do conteúdo das competências técnicas e estratégicas demonstra a importância determinante da natureza do conteúdo cognitivo do trabalho, resultante da sua semelhança entre as empresas. Digamos que a natureza técnica da actividade de trabalho se sobrepõe a outro tipo de variáveis. A análise do conteúdo das competências relacionais mostra como as configurações organizacionais e gestionárias introduzem diferenciações na sua mobilização, sendo o conteúdo destas mais favorável ao desenvolvimento de processos de aprendizagem na Hame do que Lume. A natureza das actividades de trabalho perde poder de definição no que se refere ao conteúdo das competências relacionais em benefício da sua determinação por via dos modelos de organização do trabalho e das práticas de gestão dos RH e gestão directa (figura 2).

Genericamente, o conteúdo das competências relacionais depende pouco do conteúdo cognitivo da actividade de trabalho em cada domínio de tarefas. Doutra forma, as competências relacionais dos trabalhadores a exercerem actividades de trabalho no domínio de tarefas da maquinação, manifestar-se-iam, tal como para as competências técnicas e estratégicas, idênticas em ambas as empresa. Daí considerar-se que a natureza técnica da actividade de trabalho é apropriada pelos modelos de orga- nização e de gestão da Hame e da Lume de forma diferente, e dessas diferentes formas de apropriação resulta a mobilização de competências relacionais igualmente distintas (figura 2).

Todavia, e centrando a nossa atenção sobre as competências relacionais, verifica-se que a natureza técnica da actividade de trabalho no domínio de tarefa não está completamente ausente enquanto variável diferenciadora das mesmas. A acontecer isso, teríamos, no seio da Hame, por um lado, e no seio da Lume, por outro, competências relacionais diferenciadas, mas semelhantes no seio de cada uma delas para os dois domínios de tarefas em estudo. Nesse caso, teríamos uma apropriação organizacional e gestionária da natureza técnica da actividade de trabalho igual para os diferentes tipos de actividade de trabalho. Ora, constata-se uma diferenciação do conteúdo das competências relacionais não só entre as duas empresas, mas também entre os domínios de tarefas no seio da Hame. Tal significa que essas actividades de trabalho são modeladas de forma diferente no seio das empresas do ponto de vista da mobilização das competências relacionais.

O carácter determinante do domínio de tarefas perde poder explicativo face ao conteúdo das competências técnicas, estratégicas e relacionais dos trabalhadores integrados nas actividades de trabalho da montagem. Aqui, a gestão organizacional do quotidiano de trabalho apropria-se e modela a natureza técnica das actividades de trabalho, enriquecendo-a na Hame, empobrecendo-o na Lume. Com as devidas precauções, pode-se afirmar, que, face ao conteúdo cognitivo complexo das actividades de trabalho no caso do domínio de tarefas da maquinação, as modalidades organizacionais e gestionárias das empresas tendem a não exercer um poder de apropriação forte, impondo-se, por si, o conteúdo técnico das actividades de trabalho. Por essa razão, as competências técnicas desses trabalhadores tendem a ser idênticas em ambas as empresas (quadro 1), ao invés do que acontece com as competências relacionais, completamente dependentes de configurações organizacionais e gestionárias. Já no domínio de tarefas da montagem, a simplicidade técnica da actividade de trabalho é muito mais permeável a uma modelação organizacional e gestionária, como se pode constatar pelo confronto entre os três tipos de conteúdo das competências mobilizadas nas duas empresas, que só mantêm em comum o carácter restrito do seu conteúdo técnico (quadro 1).

No que se refere às competências estratégicas, elas são duplamente condicionadas no sentido em que se lhes impõem alguns condicionalismos de ordem técnica, mas estes podem ser apropriados favorável ou desfavoravelmente pelas configurações organizacionais e gestionárias (figura 2). Daí decorre a sua semelhança no âmbito da maquinação e a sua diferenciação no âmbito da montagem, nas duas empresas (quadro 1).

Podemos concluir que o conteúdo cognitivo da actividade de trabalho, decorrente da inserção no domínio de tarefas da maquinação, determina o perfil de competências técnicas e, de alguma forma, de competências estratégicas dos trabalhadores, ao invés do que acontece no domínio de tarefas da montagem, o que significa que esta é condicionada primordialmente por uma segunda ordem de factores de carácter organizacional e gestionário, como se sistematiza na figura 2 . 
Figura 2

Principais determinações da construção social das competências profissionais

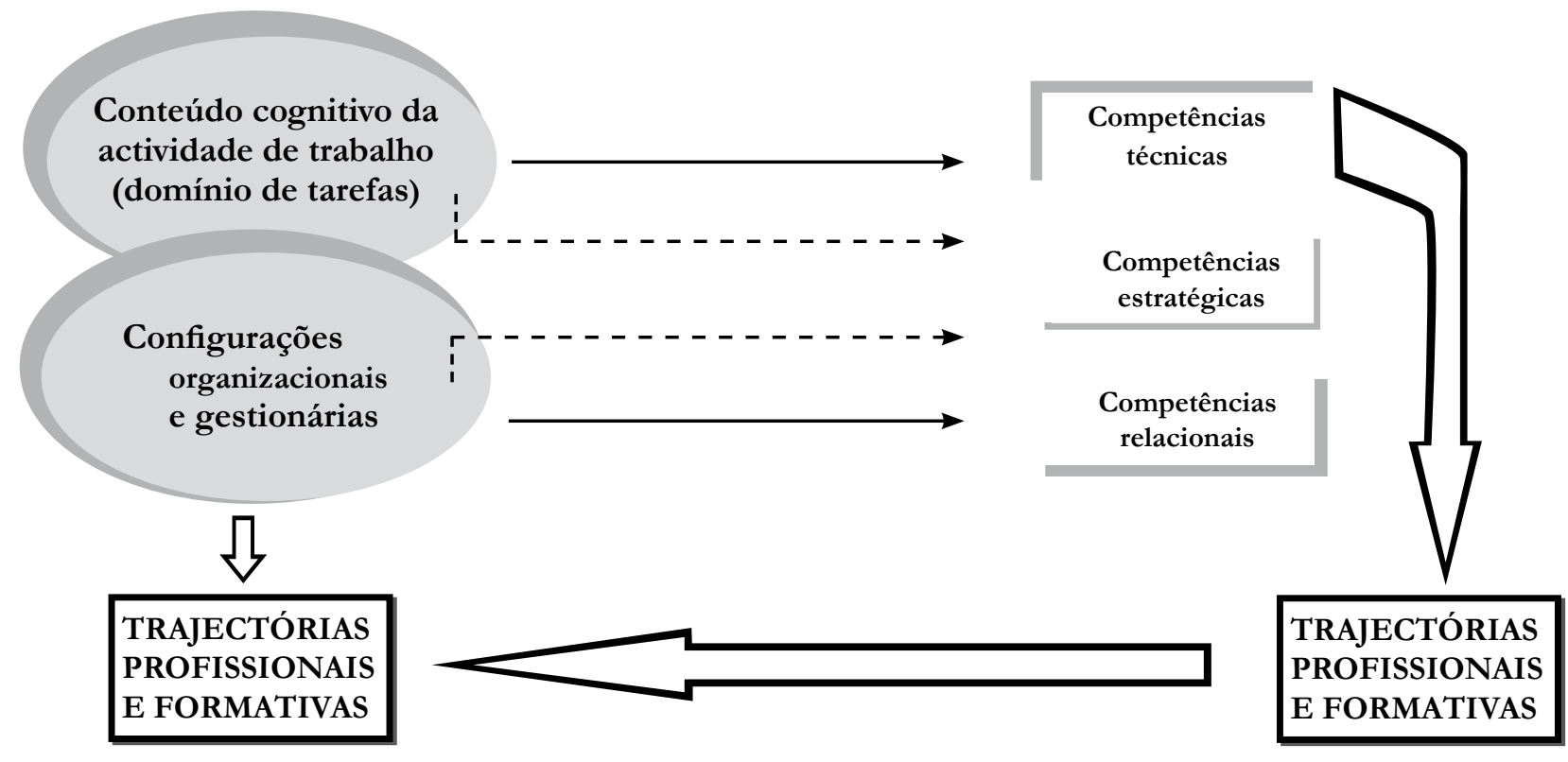

A dupla determinação das variáveis tecnológicas, por um lado, e das variáveis organizacionais e gestionárias das empresas, por outro, sobre os processos de formação de saberes e de mobilização de competências impõe uma ruptura com as perspectivas do determinismo tecnológico; porém, não permite uma adesão simplista a um determinismo socioorganizacional. Podem encontrar-se sistemas de trabalho nos quais um e outro factores se condicionam mutuamente ou um adquire primazia na sobredeterminação do outro. É necessária, porém, uma vontade política expressa por parte dos dirigentes das empresas para ultrapassar alguns dos condicionalismos impostos pelas variáveis tecnológicas. Doutra forma, pela facilidade que daí decorre, impõe-se a sobredeterminação tecnológica. É, de facto, este um dos ensinamentos a retirar: a modelação organizacional e gestionária dos conteúdos cognitivos das actividades de trabalho dos dois domínios de tarefas em análise resulta, na Hame, numa homogeneização das condições organizacionais e gestionárias de aprendizagem no sentido da igualitarização, ou seja, proporcionando um envolvimento intenso de todos os trabalhadores em práticas organizacionais de aprendizagem. Pelo contrário, na Lume, as condições organizacionais e gestionárias reproduzem, na esfera da aprendizagem, o conteúdo técnico diferenciado inerente às actividades de trabalho. Por outras palavras, as práticas organizacionais são mais favoráveis à aprendizagem no caso dos trabalhadores integrados no domínio de tarefas da maquinação e francamente desfavoráveis para os trabalhadores com actividade no domínio de tarefas da montagem.

Cremos que as condições organizacionais e gestionárias têm um papel determinante nas oportunidades de aprendizagem que se criam no seio das empresas, o que, de alguma forma, é, desde logo, indiciado pelo conteúdo das competências mobilizadas no desempenho laboral. Aquelas condicionam quer as oportuni- dades de aprendizagem criadas no exercício da actividade, quer as configurações assumidas pelos processos de aprendizagem, visto que conduzem à mobilização de competências diferenciadas face a acções técnicas de trabalho idênticas. Estas estão, por sua vez, na origem de processos de aquisição, estimulação e desenvolvimento de competências distintos que se reflectem genericamente no domínio objectivo das trajectórias profissionais e formativas (figura 2).

\section{Cremos que as condições} organizacionais e gestionárias têm um papel determinante nas oportunidades de aprendizagem que se criam no seio das empresas, o que, de alguma forma, é, desde logo, indiciado pelo conteúdo das competências mobilizadas no desempenho laboral. 


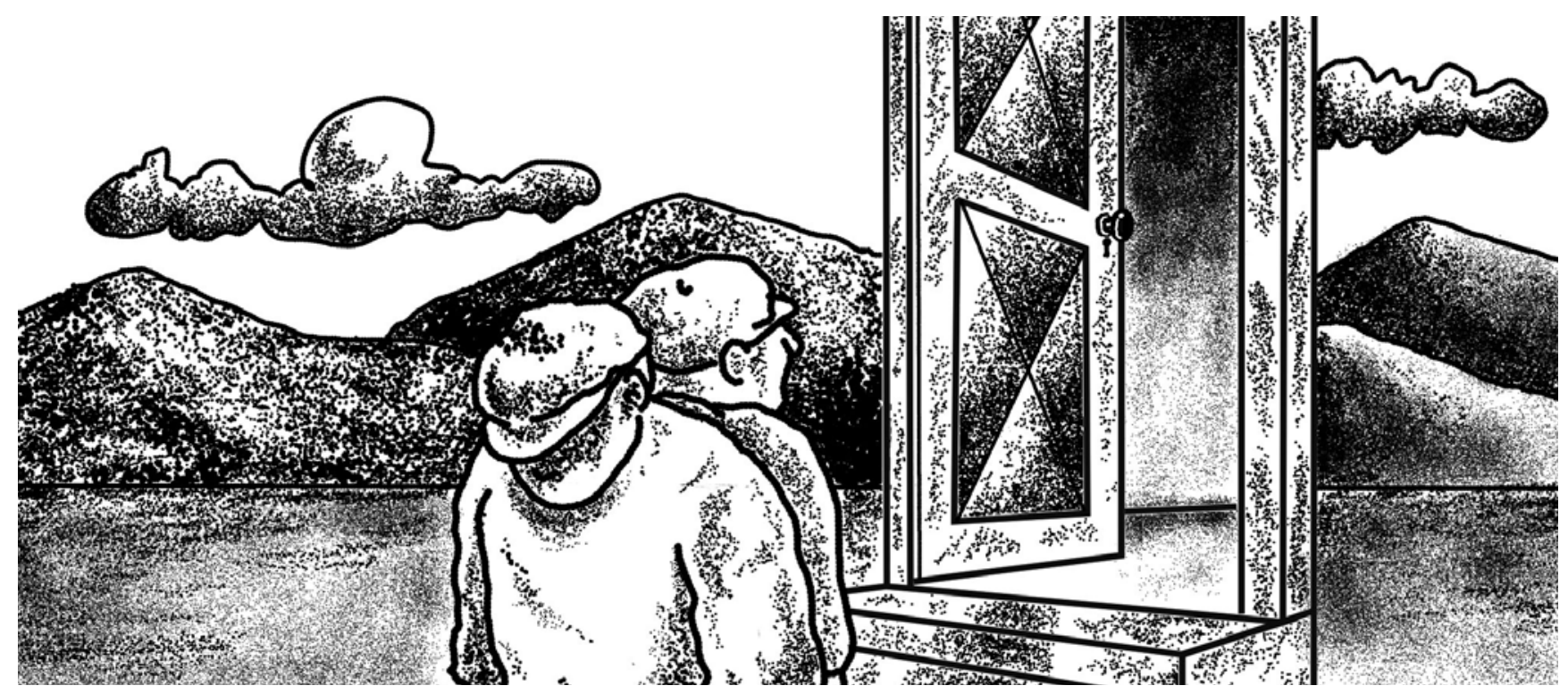

Tais condicionalismos estruturais definem as possibilidades de acção dos sujeitos, dentro dos limites e das possibilidades criadas, bem como a produção do significado atribuído às suas experiências de vida. A avaliação reflexiva dos percursos profissional e formativo experimentados, do seu desempenho laboral e da sua integração profissionais reflecte essas condições objectivas. Constata-se que a avaliação dos sujeitos sobre o seu passado e presente, assim como a projecção que perspectivam para o futuro, não é linear, nem simples.

De facto, essas avaliações assumem um carácter mais favorável e positivo na Hame do que na Lume; contudo, em ambas as empresas as trajectórias profissionais e formativas dos trabalhadores que exercem actividades de trabalho no domínio de tarefas da maquinação são sempre mais favoráveis do que as dos trabalhadores do domínio de tarefas da montagem (quadro 1). A interpretação subjectiva dos sujeitos não resulta diferenciada em termos dos domínios de tarefas, mas mais incisivamente em termos das duas empresas - significa, pois, que, nesse domínio, as configurações organizacionais e gestionárias adquirem uma importância inegável ao assumirem um peso explicativo determinante do sentido subjectivo atribuído pelos indivíduos às experiências de trabalho e de formação, manifesto na avaliação que fazem da sua aprendizagem, da imagem de si e da sua integração profissional (figura 2).

Com efeito, os trabalhadores da Hame, independentemente de se integrarem no segmento primário ou secundário do mercado interno de trabalho da empresa, apresentam sempre avaliações actuais e futuras mais optimistas. A satisfação com a gestão organizacional do quotidiano laboral manifesta-se designadamente quando a empresa se constitui, no caso da Hame, como um importante referencial identitário para a totalidade dos trabalhadores. E se essa avaliação constitui o cerne da motivação dos trabalhadores e dela resulta o seu envolvimento profissional, como comprovaram alguns autores ${ }^{35}$, então a gestão organizacional do quotidiano de trabalho da Hame encontra-se melhor posicionada em termos dos contributos que pode vir a gerar para os desempenhos empresariais. Os próprios modelos de gestão directa mais flexíveis na Hame orientam-se no sentido de estimular a motivação e o envolvimento internos em detrimento da autoridade, do controlo e da supervisão. A configuração organizacional e gestionária da Hame caracteriza-se pela diminuição da supervisão directa orientada para o trabalho em benefício de uma modalidade de supervisão orientada para o trabalhador e para o seu encorajamento do envolvimento individual e colectivo, preocupando-se com os aspectos humanos do trabalho e procurando formar boas equipas de trabalho para se atingir os objectivos definidos (BLAKE; MOUTON, 1964) ${ }^{36}$.

Tudo ponderado, estamos em condições de afirmar que, apesarde ambas as empresas apresentarem desempenhos económicos e financeiros positivos, assumem posicionamentos distintos relativamente à importância conferida aos $\mathrm{RH}$ no desenvolvimento empresarial. Permanece em aberto a tão controversa relação entre os desempenhos económicos e sociais nas empresas. A Lume apresenta desempenhos económicos e financeiros sólidos, capazes de sustentar, no futuro, uma estratégia evolutiva. Contudo, não parecem reverter a favor das práticas de gestão dos RH do núcleo operacional, caracterizadas por uma tendência imediatista e utilitarista. A Hame, apesar de apresentar resultados financeiros menos favoráveis, todavia ultrapassados no final do período em análise (triénio 1998, 1999 e 2000) e reafirmando as suas tendências evolutivas, é caracterizada por práticas de gestão dos RH mais favoráveis, de carácter desenvolvimentista e estratégico. São, de facto, orientações estratégicas diferentes que estão em causa numa e noutra empresa, as quais têm subjacentes concepções distintas do homem no trabalho e da própria gestão das pessoas nas empresas - à concepção dos RH como um custo na Lume opõe-se uma concepção de investimento na Hame, em que os primeiros são integrados numa estratégia de contenção, e os segundos, numa estratégia de capitalização.

Mais uma vez se afirma uma ambivalência das relações que, no campo económico, se estabelecem entre resultados económicos e financeiros e as orientações sócio-organizacionais das 
empresas, prevalecendo a não linearidade das mesmas, resultado da complexidade e da pluralidade de variáveis em interacção. Do ponto de vista teórico, as escolas da índole socio-económica, quer no âmbito da Sociologia, quer da Economia, tendem a afirmar uma relação positiva entre as duas variáveis em questão. Não suspeitamos dessa convergência, porém considera-se que, em vez de tal combinação ser gestionariamente demonstrada como economicamente rentável, deve ser advogada, no âmbito da actual responsabilidade social das empresas, como uma obrigação dos novos actores institucionais-chave do campo económico. O poder e o papel das empresas nos espaços nacional e transnacional deve ser condicionado a práticas socialmente responsáveis, de forma a limitar os excessos sociais do neo-liberalismo economicamente desregulado.

\section{Notas:}

1 Um maior desenvolvimento da problemática pode ser encontrado na dissertação de doutoramento da autora, intitulada Construção social das competências profissionais: dois estudos de caso em empresas multinacionais do sector da metalomecânica. Porto: Faculdade de Letras da Universidade do Porto. Dissertação de doutoramento em Sociologia. 2003. Para fundamentação dos resultados empíricos agora apresentados, cf. particularmente os capítulos 6,7 e 8 da referida dissertação.

2 ZARIFIAN, Philippe. Compétences et organisation qualifiante en milieu industriel. In MINET, F.; PARLIER, M.; WITTE, Serge de. (Orgs.) La compétence: mythe, construction ou réalité?. Paris : Ed. L' Harmattan, 1994. p. 111-133. ISBN 2-7384-2683-2.

3 VALENTE, A. Cláudia. Perfis e competências estratégicas: uma perspectiva intersectorial. In: SEMINÁRIO: DESENVOLVIMENTO DE COMPETÊNCIAS, COMPETITIVIDADE E CIDADANIA, Lisboa : Inofor, 1999. p. 8. ISBN 972-8619-00-6.

4 ZARIFIAN, Philippe. La politique de la compétence et l'appel aux connaissances à partir de la stratégie d'entreprise post-fordiste. Colloque de Nantes. [Em linha]. (2002a) Disponível em: http://perso.wanadoo.fr/philippe. zarifian/page64.htm; Id. Gestão da e pela competência. In: SEMINÁRIO INTERNACIONAL: EDUCAÇÃO PROFISSIONAL, TRABALHO E COMPETÊNCIA. Paris: Presses Universitaires de France, 1996a . ISBN 2-13-047357-1

5 ZARIFIAN, Philippe. Gestão da e pela competência. In: SEMINÁRIO INTERNACIONAL: EDUCAÇÃO PROFISSIONAL, TRABALHO E COMPETÊNCIA. Paris : Presses Universitaires de France, 1996a. p. 1. ISBN 2-13-047357-1; Id. La politique de la compétence et l'appel aux connaissances à partir de la stratégie d'entreprise post-fordiste. In: Colloque de Nantes. [Em linha].2002a,Disponível em: $<$ http://perso.wanadoo.fr/philippe. zarifian/page64.htm>, p. 3 .

\section{${ }^{6}$ Id. ibid.}

Definiram-se três tipos de modalidades de gestão de RH a partir da análise das práticas no âmbito dos subsistemas de gestão do emprego e da mobilidade, das remunerações e da formação: a gestão de RH imediatista e utilitarista; a gestão de RH adaptativa e de ajustamento; a gestão de RH desenvolvimentista e estratégica. Para um maior desenvolvimento, cf. PARENTE, Cristina. Avaliação de impacto da formação sobre as trajectórias profissionais e a competitividade empresarial: um ensaio em empresas do sector têxtil do Vale do Ave. Lisboa : Instituto Superior de Ciências do Trabalho e da Empresa. Dissertação de mestrado em Políticas e Gestão de Recursos Humanos, 1995. p. 65-70. Nesse trabalho, àqueles subsistemas acrescentou-se a análise do subsistema de informação e de comunicação. Cf. PARENTE, Cristina (2003), op. cit., p.315-330.

8 LE BOTERF, Guy. L'ingénierie des compétences. Paris : Ed. d'Organisations, 1998a. p. 27. ISBN 2-7081-2126-X.

9 PARENTE, Cristina. (1995), op. cit.

${ }^{10}$ A especificidade das qualificações, a formação interna nas empresas, particularmente de carácter informal, e a lei consuetudinária são consideradas por Doeringer e Piore (1985, p. 57-74) como os factores que explicam a constituição dos mercados internos de trabalho. DOERINGER, Peter B.; PIORE, Michael. Internal labor markets and manpower analysis. New York : M. E. Sharpe, 1985. ISBN 0-87332-351-3.

${ }^{11}$ MARSDEN, D. Marchés du travail: limites sociales des nouvelles théories. Paris : Economica, 1989. p. 219. ISBN 2-7178-1756-5.

${ }^{12}$ PARENTE, Cristina. (1995), op. cit.

${ }^{13}$ ZARIFIAN, Philippe. (1996a), op. cit., p. 9.

${ }^{14}$ Id. La compétence en débat. Paris : Le Monde,1998a.

${ }^{15}$ LE BOTERF, Guy. De la compétence à la navigation professionnelle. Paris : Ed. d'Organisations, 1997. p. 41. ISBN 2-7081-2021-X.

${ }^{16}$ ZARIFIAN, Philippe. La compétence en débat. Paris : Le Monde, 1998a.

${ }^{17}$ Id. La nouvelle productivité. Paris : Ed. L'Harmattan, 1998b. ISBN 2-7384722-6.

${ }^{18}$ O conceito de modelos de gestão directa designa, ainda que com novos contornos, o que classicamente se define como modelos hierárquicos, ou seja, os sistemas de fluxos regulados de controlo e os mecanismos de coordenação na acepção de (Mintzberg, (1995), os quais são determinados pelos modelos organizacionais e de gestão macro, definidos no contexto global das empresas. Os responsáveis directos operacionalizam ao nível micro as estratégias definidas pela direcção. Para tal, dispõem de um grau de autonomia relativo face à mesma, sendo responsáveis pelo processo de tomada de decisão que tem lugar no interior de cada unidade funcional. De acordo com os critérios, grau de directividade do respectivo líder, autonomia concedida aos subordinados, grau de participação dos mesmos nas decisões da unidade e estilo de supervisão, consideram-se dois modelos de gestão directa - os modelos rígidos e os modelos flexíveis. Nos primeiros, as práticas de interacção com os subordinados e as práticas de gestão dos $\mathrm{RH}$ orientam-se pelas directivas burocráticas, assumindo os responsáveis directos os papéis de vigilante, controlador e disciplinador dos desempenhos individuais. A supervisão é orientada para o trabalho, na medida em que se encontra associada ao desempenho de um trabalho fragmentado e parcelar, sobre o qual é possível exercer uma actividade de controlo intensa, dada a pré-definição e a afectação de actividades a cada trabalhador (BLAKE; MOUTON, 1964). Os desempenhos dos trabalhadores do núcleo operacional devem seguir rigorosamente as normas de trabalho prescritas. Desse modo, as funções do responsável directo centram-se no interior da unidade funcional. Os referenciais teóricos que inspiram o modelo de gestão rígido remetem para as teorias organizacionais clássicas. Nos modelos de gestão flexíveis, as práticas de interacção com os subordinados e as práticas de gestão dos RH orientam-se pelas directivas da valorização e reconhecimento dos $\mathrm{RH}$, assumindo os responsáveis directos os papéis de orientador, formador e facilitador dos desempenhos individuais. A supervisão é orientada para o trabalhador dado que a preocupação incide sobre os aspectos humanos do trabalho. Procura-se formar boas equipas de trabalho para se atingirem os objectivos definidos (BLAKE; MOUTON, 1964), atendendo igualmente às expectativas dos subordinados e valorizando as suas potencialidades e características pessoais e profissionais. O conteúdo do trabalho do núcleo operacional é ampliado, adquirindo maior autonomia, pelo que o responsável directo fica liberto para assumir funções centradas na gestão das fronteiras. Os referenciais teóricos que inspiram o modelo de 
gestão flexível remetem para as teorias organizacionais inspiradas na Escola Sociotécnica. (MINTZBERG, Henry. Estrutura e dinâmica das organizações. Lisboa : Publicações D. Quixote, 1995. ISBN 972-20-1147-20; BLAKE, Robert R.; MOUTON, Jane S. The managerial grid. Houston : Gulf Publishing Company,1964. ISBN 0-88415-252-9.)

${ }^{19}$ A tipologia de competências construída assenta na seguinte definição conceptual: as competências técnicas remetem para um conjunto de capacidades para realizar acções de trabalho coerentes e distintas no seio de um determinado domínio de tarefas, bem como para as diversas intervenções práticas que essas acções parcelares implicam. A relação dos trabalhadores com o equipamento técnico e igualmente os procedimentos pelos quais dominam a tecnologia da actividade de trabalho constituem os factores estruturadores deste tipo de competência. As competências estratégicas dizem respeito ao grau de controlo que os trabalhadores exercem sobre as acções de trabalho, à qualidade da sua execução, à responsabilidade, à autonomia e à iniciativa presentes nas suas decisões e acções. $O$ domínio da resolução das perturbações, não tanto no que se refere às intervenções desencadeadas, mas, particularmente, no que diz respeito ao grau de envolvimento na resolução, integra-se nesse tipo de competências. Não é o conteúdo da resolução propriamente dita que está em causa - o que remete para as competências técnicas -, mas a possibilidade de actuar correctivamente, o grau de autonomia detido na prática correctiva e o envolvimento que estas acções implicam. Finalmente, as competências relacionais remetem para o conjunto de acções dirigidas a outros sujeitos que participam no processo de trabalho. São transversais às competências técnicas e estratégicas, básicas para uma participação reflexiva no processo de trabalho e decisivas em termos das capacidades de aprendizagem, para as quais a interactividade é, como já analisado, uma das suas condicionantes.

${ }^{20}$ Tratam-se de nomes fictícios de modo a garantir o anonimato das empresas.

${ }^{21}$ MALGLAIVE, Gérard. Ensinar adultos. Porto : Porto Editora, 1995. ISBN 972-0-34116-5.

${ }^{22}$ Optou-se por não referenciar valores numéricos de fundamentação da informação, dado que tornaria o conteúdo do artigo maçador e demasiado longo. Estes podem ser consultados em PARENTE (2003), op. cit., cap. 6, 7 e 8.

${ }^{23}$ KOVÁCS, I.Da controvérsia sobre os novos modelos de produção. In KOVÁCS, I.; CASTILLO, Juan José, (Orgs.). Novos modelos de produção: trabalho e pessoas. Oeiras : Celta Ed., 1998b. ISBN 972-8027-96-6, p. 5-24.; Id. Sistemas antropocêntricos de produção: uma alternativa para a Europa? In: KOVÁCS, I.; CASTILLO, Juan José (Eds.). Novos modelos de produção: trabalho e pessoas. Oeiras : Celta Ed., 1998c. p. 93-114. ISBN 972-8027-96-6.

${ }^{24}$ MINTZBERG, Henry (1995), op. cit.

${ }^{25} \mathrm{O}$ que contribui para aproximar o conteúdo das competências técnicas e estratégicas dos trabalhadores de ambas as empresas.

${ }^{26}$ MALGLAIVE, Gérard (1995), op. cit.

${ }^{27}$ KOVÁCS, I. (1998b; 1998c), op. cit.

${ }^{28}$ MINTZBERG, Henry (1995), op. cit.

${ }^{29}$ ZARIFIAN, Philippe (2002a), op. cit.

${ }^{30}$ Cf. nomeadamente KOVÁCS, I. Trabalho, qualificações e aprendizagem ao longo da vida: ilusões e problemas da sociedade de informação. In APSIOT (Org). Formação, trabalho e tecnologia: para uma nova cultura organizacional. Oeiras : Celta, 1998a. p. 69-84. VII Encontro Nacional. Ed. ISBN 972-774-021-9, e CASACA, Sara Falcão. O envolvimento dos trabalhadores no melhoramento contínuo (kaizen): um estudo de caso. Organizações e Trabalho, n. 20 (1998), p. 63-74, 1998. ISSN 0871-4835, para o caso português.

${ }^{31}$ MARSDEN, D. (1989), op. cit.

${ }^{32}$ DOERINGER, Peter B.; PIORE, Michael.(1985) op. cit.
${ }^{33}$ MARSDEN, D. (1989), op. cit.

${ }^{34}$ DOERINGER, Peter B.; PIORE, Michael (1985), op. cit.

${ }^{35}$ Entre outros autores que postulam esta tese, cf. nomeadamente DES HORTS, C. BESSEYRE,H. Vers une gestion stratégique des ressources humaines. Paris : Ed. d'Organisation. 1988.ISBN 2-7081-0871-9.

${ }^{36}$ BLAKE, Robert R.; MOUTON, Jane S (1964), op. cit.

\section{ABSTRACT}

Cristina Parente. Developing and managing competences: the case of multinational companies in the metal-mechanic sector in Portugal.

The central objective of this article is the problem of social construction of vocational competences. It discusses the main results from a research project focused on two case studies carried out in multinational metal-mechanic companies located in Portugal. Modalities for managing competences are studied based on the logic for producing knowledges and mobilizing competences, taking into account both the viewpoint of managers and wage workers. This reflection concludes with a discussion on the main business determinants for the social construction of vocational competences.

Keywords: Competence; Knowledges; Company; Work Organization; Management Models.

\section{RESUMEN}

Cristina Parente. Formar y gestionar capacidades: el caso de empresas multinacionales del sector metalmecánico en Portugal.

El objetivo central de este articulo es abordar la problemática de la construcción social de las capacidades profesionales. Se discuten los principales resultados de un proyecto de investigación que incidió sobre dos estudios de casos realizados en empresas multinacionales del sector metalmecánico instaladas en Portugal. Se estudian las modalidades de gestión de capacidades a partir del análisis de la lógica de producción de conocimientos y de la movilización de capacidades, teniendo en cuenta tanto el punto de vista de los dirigentes como el de los asalariados. Se finaliza la reflexión discutiendo los principales determinantes empresariales de la construcción social de las capacidades profesionales.

Palabras clave: Capacidades; Conocimientos; Empresa; Organización del Trabajo; Modelos de Gestión. 